\title{
Terpyridine derivatives functionalized with (hetero)aromatic groups and the corresponding Ru complexes: Synthesis and characterization as SHG chromophores
}

\author{
Sara S.M. Fernandes ${ }^{\mathrm{a}}$, Michael Belsley ${ }^{\mathrm{b}}$, Carlo Ciarrocchi ${ }^{\mathrm{c}}$, Maurizio Licchelli ${ }^{\mathrm{c}}$, \\ M. Manuela M. Raposo, \\ ${ }^{a}$ Centro de Química, Universidade do Minho, Campus de Gualtar, 4710-057, Braga, Portugal \\ b Centro de Física, Universidade do Minho, Campus de Gualtar, 4710-057, Braga, Portugal \\ ${ }^{\mathrm{c}}$ Departimenti di Chimica, Università di Pavia, via Taramelli 12, 27100 Pavia, Italy
}

\section{A R T I C L E I N F O}

\section{Keywords:}

Terpyridine

Push-pull heterocyclic ligands

Ruthenium complexes

Second-harmonic generators (SHG)

\begin{abstract}
A B S T R A C T
Push-pull terpyridine derivatives 3 were synthesized and characterized in order to study the variations produced in their optical and electronic properties by linking different (hetero)aromatic electron donor moieties at 4'position of the electron deficient terpyridine moiety. The final donor-acceptor systems 3a-g were synthesized in fair to good yields by Kröhnke condensation of the precursor aldehydes 1, with 2-acetylpyridine 2. HyperRayleigh scattering in dioxane solutions using a fundamental wavelength of $1064 \mathrm{~nm}$ was employed to evaluate their second-order nonlinear optical properties. Terpyridine derivative $\mathbf{3 g}$ functionalized with the 9-ethyl-9Hcarbazolyl group exhibited the largest first hyperpolarizability $\left(\beta=610 \times 10^{-30}\right.$ esu, using the T convention) thus indicating its potential application as a second harmonic generation (SHG) chromophore. Terpyridine derivatives 3 were also used as ligands for the synthesis of novel $\left[\mathrm{Ru}^{\mathrm{II}}(\mathrm{tpy})(\mathrm{NCS})_{3}\right]^{-}$complexes, prepared in good yields by a two-step procedure involving the preparation of $\left[\mathrm{Ru}^{\mathrm{III}}(\mathrm{tpy})\left(\mathrm{Cl}_{3}\right)\right]$ as intermediates. Ruthenium ${ }^{\mathrm{II}}$ complexes display a broad absorption in the visible range, accounting for their very dark color. Their redox behaviour is mainly characterized by the $\mathrm{Ru}^{\mathrm{II}}-\mathrm{Ru}^{\mathrm{III}}$ oxidation and by the ligand-centered reduction, whose potentials can be finely tuned by the electronic properties of the aromatic substituents on the terpyridine ligand. Hyper-Rayleigh scattering in methanol solutions using a fundamental wavelength of $1064 \mathrm{~nm}$ was also employed to evaluate their second order nonlinear optical properties.
\end{abstract}

\section{Introduction}

$2,2^{\prime}: 6^{\prime}, 2^{\prime \prime}$-Terpyridine (tpy) derivatives are very interesting heterocyclic systems that have been the subject of extensive studies since their first description in the early 1930s. A wide range of derivatives have already been prepared by introducing different substituents onto the terpyridine core, which contain three nitrogen atoms that enables chelating with a wide range of transition metals, and even lanthanide ions [1].

The terpyridine group commonly acts as a metal-binding site, usually a terdentate donor, although some reports of the ligand acting as a bidentate or monodentate donor can be found. In adopting the chelating terdentate bonding mode, it is necessary for the ligand to change conformation from the typical trans, trans conformation observed in the free ligand to cis, cis. The great stability of the coordination compounds with transition metals is in part due to the thermodynamic chelate effect, and to the $\sigma$-donor/ $\pi$-acceptor character of the metal-to-ligand bond. The metal ion definitely plays a critical role, both in determining the chemical and photophysical properties of the complex, and also in controlling the kinetics of assembly and the overall lability or inertness of the complex. Another interesting matter is the possibility of differently functionalized terpyridine ligands being coordinated to the same metal ion [2].

Due to their distinct photophysical, electrochemical, catalytic and magnetic properties, terpyridines and their complexes have been studied regarding a wide range of potential applications such as photovoltaics [3], light emitting electrochemical cells (LECs) [4], and nonlinear optics. Nevertheless only a few articles described the evaluation of the SHG properties of terpyridine ligands as well as the corresponding metal complexes [5]. Moreover, ditopic and dendritic terpyridine ligands can form polymetallic species, which may be utilized as luminescent or electrochemical sensors [6]. Their biomedical and

\footnotetext{
* Corresponding author.

E-mail address: mfox@quimica.uminho.pt (M.M.M. Raposo).
} 

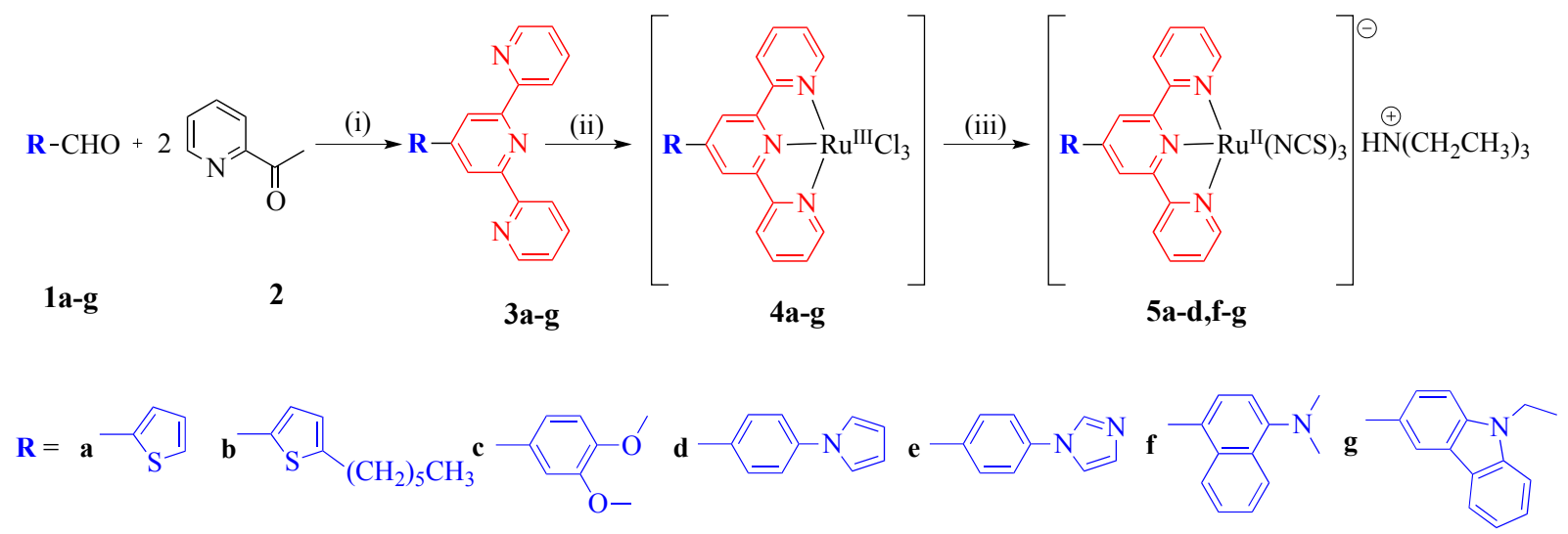

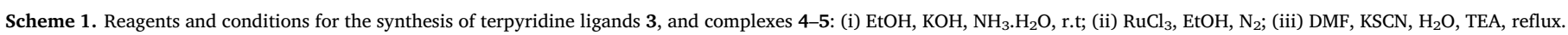

pharmaceutical applications are currently fast-growing fields of research, ranging from colorimetric metal determination to DNA binding agents and anti-tumour research [7]. Furthermore, terpyridines and their transition metal complexes has been also employed for catalytic applications such as in asymmetric catalysis [8] in oxidation of alcohols [9], carbonylation of aromatic compounds [10], hydroformylation reactions [11] and as oxygen-binding molecules [12]. One of the most promising fields for new terpyridine compounds is their application in supramolecular chemistry [13].

The use of $2,2^{\prime}: 6^{\prime}, 2^{\prime \prime}$-terpyridines for this wide range of potential applications and research areas requires a high structural variability of the basic terpyridine subunit. Therefore, a highly efficient and simple ligand synthesis is as essential as the well-defined derivatization at every ring position. In particular, the terpyridine derivatives featuring $\pi$-conjugated substituents, commonly attached in the $4^{\prime}$-position, are of increasing interest as it provides a means of directionality, and thus a means of linear communication can occur along the coordination axis, without changing the centrosymmetric nature or forming enantiomers. Functional groups may be introduced directly in the course of the terpyridine preparation or by a variety of functional group conversion reactions. To this date, a large range of derivatives have been prepared by introducing different substituents onto the terpyridine core using several synthetic procedures, by varying the substitution pattern of the tpy moiety or the nature of the metal, and finally the character of the other ligands involved in the coordination sphere [14].

The first terpyridine synthesis was reported in 1932 by Morgan and Burstall who isolated tpy in poor yield as a by-product of a bipyridine synthesis, obtained by dehydrogenation of pyridine in the presence of anhydrous ferric chloride [15]. Since then, a multitude of protocols for the preparation of the basic terpyridine structure and the introduction of various substituents have been published. Tpy derivatives are mainly prepared through two basic synthetic approaches, which involve either ring assembly or coupling methodologies.

The most common preparation of terpyridines by ring assembly reaction is the well-known Kröhnke condensation. Introduced in 1976, this synthetic method is based on ring closure of 1,5-diketones in the presence of an ammonia source. This methodology was applied to the preparation of various $4^{\prime}$-substituted tpy derivatives, the suitable 1,5diketone intermediate being obtained by a Michael addition between a pyridinium salt and an $\alpha, \beta$-unsaturated ketone. The desired $\alpha, \beta$-unsaturated ketone was prepared by an aldol condensation between 2 acetylpyridine derivatives and an aldehyde in an alkaline media, with subsequent isolation of the product [16].

Although ring assembly is still the most prevalent strategy, modern palladium-catalyzed cross-coupling procedures have become increasingly competitive over the last few years and may eventually supersede ring closure reactions due to their multiplicity and efficiency. Modern palladium(0)-catalyzed coupling reactions like Suzuki [17] and Stille
[18] couplings combine the desired efficiency and simplicity with controllable substitution possibilities. The Stille cross-coupling, in particular, has become a popular terpyridine preparation route, due to its universal buiding-block principle, its multigram product accessibility and the well-directed functionalization at almost every desired position of the terpyridine rings [19]. The electron poor pyridines are less effective in the Suzuki reaction due to the weaker nucleophilicity of pyridyl-boronates with respect to other organometallic reagents, such as the organo-tin involved in Stille reaction [20]. However, these approaches suffer from the poor availability of the required starting materials. The synthesis often involves harsh reaction conditions, many functional groups are not tolerated and the isolated yields are in many cases remarkably poor. Other known methods of achieving tpy derivatives are the Tohda [21] and the Sauer [22] methodologies, or even the pyrolysis of hydrazonium salts [23].

During the last decade, our research group has reported a large number of push-pull $\pi$-conjugated heterocyclic systems as well as the corresponding metal complexes bearing electron-deficient azine (pyridine, quinoline, phenanthroline), diazine (pyridazine or phthalazine derivatives) or flavin derivatives which act simultaneously as electron acceptors and receptor moieties. These systems have found several applications such as SHG chromophores [24], optical chemosensors [25], DNA intercalators [26], heterogeneous catalysts [27], etc.

Based on our earlier work we were motivated to extend these studies in order to explore the potential application of push-pull substituted tpy derivatives $\mathbf{3}$ as well as the corresponding Ru complexes $\mathbf{5}$ in which the terpyridine system plays the dual role of acceptor group and receptor moiety for the complexation with $\mathrm{Ru}$ (Scheme 1). The purpose of this investigation is to evaluate the tuning of linear and nonlinear optical and electronic properties of novel donor-acceptor substituted terpyridines $\mathbf{3}$ and their $\mathrm{Ru}$ complexes $\mathbf{5}$ that can be achieved by functionalization of these systems with donor groups $/ \pi$ bridges with different electronic nature (aromatic or heteroaromatic, functionalized with alkoxy or $N, N$-dialkylamino- groups) linked to the terpyridine electron deficient system. Consequently, two new series of heterocyclic chromophores $\mathbf{3}$ and their Ru complexes $\mathbf{5}$ have been designed and synthesized and the influence of the donor groups/ $\pi$-spacers was studied by combined experimental studies of the electronic, linear and nonlinear optical properties of these push-pull systems.

\section{Results and discussion}

\subsection{Synthesis and characterization}

A series of 2,2': $6^{\prime}, 2^{\prime \prime}$-terpyridines with donor groups attached in the $4^{\prime}$-position were designed in order to study the effect of the different substituents on the optical and electronic properties of the molecule and to be further used as organic ligands in the preparation of $\mathrm{Ru}^{\mathrm{II}}$ 
complexes. All terpyridine ligands were synthesized, in fair to good yields (20-69 \%) by Kröhnke condensation, a ring assembly methodology, between 2-acetylpyridine 2, and aldehyde precursors 1a-g bearing the selected donor groups, in the presence of ammonia and potassium hydroxide (Scheme 1). The pure ligands were obtained after washing the resulting precipitate with ice-cold aqueous solution of ethanol (50\%) and drying under reduced pressure. The donor moieties used are not only of aromatic nature like 3,4-dimethoxyphenyl or $\mathrm{N}, \mathrm{N}$ dimethylnaphthalen-1-amine, but heteroaromatic donor groups such as thiophene or pyrrole were also employed. Ligands 3a [28], 3c [28b,29], 3e [30], and 3g [6i], have been already reported and used in supramolecular chemistry, bioimaging and/or DNA targeting. On the other hand, the novel ligands $\mathbf{3 b}$, $\mathbf{3 d}$, $\mathbf{3}$ f were completely characterized by the usual spectroscopic techniques.

The synthesis of the novel $\left[\mathrm{Ru}^{\mathrm{II}}(3)(\mathrm{NCS})_{3}\right]^{-}$complexes 5 , was performed in two steps, as previously described for similar $\mathrm{Ru}^{\mathrm{II}}$ complexes [3c]: (i) preparation of $\left[\mathrm{Ru}^{\mathrm{III}}(3) \mathrm{Cl}_{3}\right]$ intermediate complexes 4 , by reaction of the corresponding ligands 3 with ruthenium(III) chloride in refluxing ethanol under an inert atmosphere; (ii) synthesis of the desired final complexes 5 by refluxing a mixture of $\mathbf{4}$ and potassium thiocyanate in water/DMF (1:2) in the presence of trimethylamine. Substitution of anionic ligands and reduction of metal center take place in the same step, as $\mathrm{SCN}^{-}$induces a larger ruthenium(II) stabilization. The intermediate complexes 4 are insoluble and were used directly for the second reaction step without characterization. The final isolated products were obtained in fair to good overall yields (34-59\%) as black solids, and are a mixture of two isomers due to the ambidentate nature of the thiocyanate ligands [31]. Reaction for the preparation of complex 5e provided a highly insoluble product, likely a polymeric coordination compound involving the residual coordinating ability of imidazole moiety on tpy 3e. Due to its insolubility this product was not considered for further studies.

\section{2. ${ }^{1} H$ NMR and FTIR studies}

An analysis of the structures and charge transfer transitions of terpyridine push-pull chromophores 3 was made by ${ }^{1} \mathrm{H}$ NMR spectroscopy (Table 1). The ${ }^{1} \mathrm{H}$ NMR chemical shifts reflect a charge separation in the ground state. Therefore, the analysis of these data in push-pull derivatives 3 functionalized with different donor groups linked to the terpyridine acceptor moiety also confirms their push-pull character with a significant intramolecular charge transfer (ICT) from the donor to the acceptor group and a high polarizability of the whole donor-acceptor $\pi$ conjugated systems.

The relative electron donating strength of the donor moiety attached to the terpyridine core in $4^{\prime}$-position can be estimated through the analysis of the ${ }^{1} \mathrm{H}$ NMR spectra, for example, by comparison of the chemical shift for $3^{\prime}$ - and $5^{\prime}-\mathrm{H}$ of the terpyridine core, which are, in this case, the protons in the electron withdrawing moiety with better resolution. The signal under consideration appears as a singlet that integrates two protons $\left(3^{\prime}-\right.$ and $\left.5^{\prime}-\mathrm{H}\right)$ due to the lack of other

Table 1

Yields, UV-visible absorption, emission and ${ }^{1} \mathrm{H}$ NMR data for terpyridine ligands 3.

\begin{tabular}{|c|c|c|c|c|c|c|c|}
\hline \multirow[t]{2}{*}{ Cpds } & \multirow[t]{2}{*}{$\eta(\%)$} & \multicolumn{2}{|c|}{ UV-Vis } & \multicolumn{3}{|c|}{ Fluorescence } & \multirow{2}{*}{$\begin{array}{l}{ }^{1} \mathrm{H} \text { NMR } \\
\delta_{\mathrm{H}} \\
3^{\prime}-\text { and } 5^{\prime}- \\
\mathrm{H}(\mathrm{ppm})\end{array}$} \\
\hline & & $\begin{array}{l}\lambda_{\max } \\
(\mathrm{nm})\end{array}$ & $\varepsilon\left(\mathrm{M}^{-1} \mathrm{~cm}^{-1}\right)$ & $\lambda_{\mathrm{em}}(\mathrm{nm})$ & $\Phi_{\mathrm{F}}$ & $\begin{array}{l}\text { Stokes' } \\
\text { shift (nm) }\end{array}$ & \\
\hline $3 \mathbf{a}$ & 53 & 286 & 25,778 & 359 & 0.59 & 73 & 8.62 \\
\hline $3 b$ & 20 & 292 & 29,333 & 389 & 0.55 & 97 & 8.56 \\
\hline $3 c$ & 55 & 286 & 24,083 & 435 & 0.24 & 149 & 8.62 \\
\hline $3 d$ & 26 & 283 & 22,675 & 412 & 0.06 & 129 & 8.73 \\
\hline $3 e$ & 69 & 274 & 32,631 & 354 & 0.21 & 80 & 8.69 \\
\hline $3 f$ & 51 & 288 & 25,258 & 413 & 0.09 & 125 & 8.35 \\
\hline $3 g$ & 33 & 292 & 31,532 & 436 & 0.27 & 144 & 8.83 \\
\hline
\end{tabular}

neighbouring protons and the equivalent magnetic field experienced by both (Table 1). A stronger electron donating ability of the donor moiety, improves the internal charge transfer (ICT) in the push-pull system, moving the electron density towards the acceptor end group. On account of the additional electron density, an upfield shift of the aforementioned singlet is expected (decrease of the chemical shift), due to the weaker magnetic field felt by the nuclei. Ligands $\mathbf{3 d}, \mathbf{3 e}$ and $\mathbf{3 g}$, functionalized with a pyrrolyl-1H-phenyl, imidazolyl- $1 H$-phenyl or $N$ ethylcarbazolyl groups, respectively, present the highest chemical shift for the $3^{\prime}-$ and $5^{\prime}-\mathrm{H}$ at $\delta 8.76,8.69$ and $8.83 \mathrm{ppm}$, respectively, suggesting the weakest electron donor effect probably due to the resonance effect of the aromatic rings. Ligands $\mathbf{3 a}$, and $\mathbf{3 c}$ exhibit a singlet for the same protons at $\delta 8.62 \mathrm{ppm}$. For ligands $3 \mathrm{~b}(\mathrm{R}=5$-hexylthiophene) and $\mathbf{f}(\mathrm{R}=N, N$-dimethylnaphthalen-1-amine $), 3^{\prime}$ - and $5^{\prime}-\mathrm{H}$ are the most upfield positioned of all the compounds ( $\delta 8.56$ and $8.35 \mathrm{ppm}$, respectively) indicating the strongest relative donating effect among the employed substituents.

For all $\left[\mathrm{Ru}^{\mathrm{II}}(3)(\mathrm{NCS})_{3}\right]^{-}$complexes, the ${ }^{1} \mathrm{H}$ NMR spectra showed two signals at $\delta 1.26$ and $3.14 \mathrm{ppm}$ (a triplet that integrates for 9 protons and a quartet integrating for 6 protons, respectively) that are attributed to the $\mathrm{Et}_{3} \mathrm{NH}^{+}$counterion. The spectra also indicate the presence of two isomers for each compound, which has been previously observed in analogous $\mathrm{Ru}^{\mathrm{II}}$ complexes. The formation of the isomers is caused by the ambidentate nature of the thiocyanate ligand that can be N-or S-bound. Most of the signals of the two isomers are overlapped, therefore only the data of the most abundant isomer is reported. The isomeric ratio was estimated from the integrals of the most separated peak at $\delta$ $\sim 8.4 \mathrm{ppm}$ [31b].

The isomeric composition of complexes 5 can also be studied by FTIR spectroscopy. In fact, the $\mathrm{SCN}^{-}$coordination mode is expected to considerably affect stretching frequencies of C-N and C-S bonds in thiocyanate ligand. In analogous ruthenium(II) complexes it was observed that the $\nu$ (C-N) band occurs at a slightly higher frequency for the S-bound isomer, although the two peaks are not resolved when both isomers are present in comparable amount. On the other hand, it has been reported that the $\nu$ (C-S) band falls at distinct frequencies in the two isomers (higher for the N-coordinated thiocyanate) and displays different intensities (more intense for the S-bound isomer) [31b-c]. Stretching frequency data pertaining to coordinated thiocyanate, obtained from FTIR measurement performed on the examined complexes $\mathbf{5}$ are collected in Table 2 (and in Supporting Information).

Complexes 5 present two bands compatible with the expected $v$ (CS) transitions: one falling in the $780-790 \mathrm{~cm}^{-1}$ range and the other close to $750 \mathrm{~cm}^{-1}$. On the basis of literature data [31b-c], they can be ascribed to the N-bound and S-bound isomers, respectively. The presence of both bands suggests the existence of at least two isomers, in agreement with data from the ${ }^{1} \mathrm{H}$ NMR spectra. The bands centred at about $785 \mathrm{~cm}^{-1}$ (N-bound $\mathrm{NCS}^{-}$) appear to be more intense than the corresponding bands positioned at about $750 \mathrm{~cm}^{-1}$ (S-bound $\mathrm{NCS}^{-}$), suggesting that the more abundant form should be the $\left[\mathrm{Ru}^{\mathrm{II}}(3)(\mathrm{NCS})_{3}\right]^{-}$ (N-bound) isomer.

It should be noted that only one signal ascribed to C-N stretching of coordinated thiocyanate could be observed at about $2100 \mathrm{~cm}^{-1}$ in all

Table 2

Stretching frequencies for coordinated thiocianate in complexes $\mathbf{5}$.

\begin{tabular}{llll}
\hline \multirow{2}{*}{ Complex } & $\nu(\mathrm{C}-\mathrm{N})\left(\mathrm{cm}^{-1}\right)$ & \multicolumn{2}{l}{$\nu(\mathrm{C}-\mathrm{S})\left(\mathrm{cm}^{-1}\right)$} \\
\cline { 3 - 4 } & & N-bound & S-bound \\
\hline $\mathbf{5 a}$ & 2093 & 781 & 750 \\
$\mathbf{5 b}$ & 2093 & 782 & 752 \\
$\mathbf{5 c}$ & 2095 & 783 & 752 \\
$\mathbf{5 d}$ & 2097 & 785 & 752 \\
$\mathbf{5 f}$ & 2104 & 791 & 754 \\
$\mathbf{5 g}$ & 2095 & 784 & 748 \\
\hline
\end{tabular}



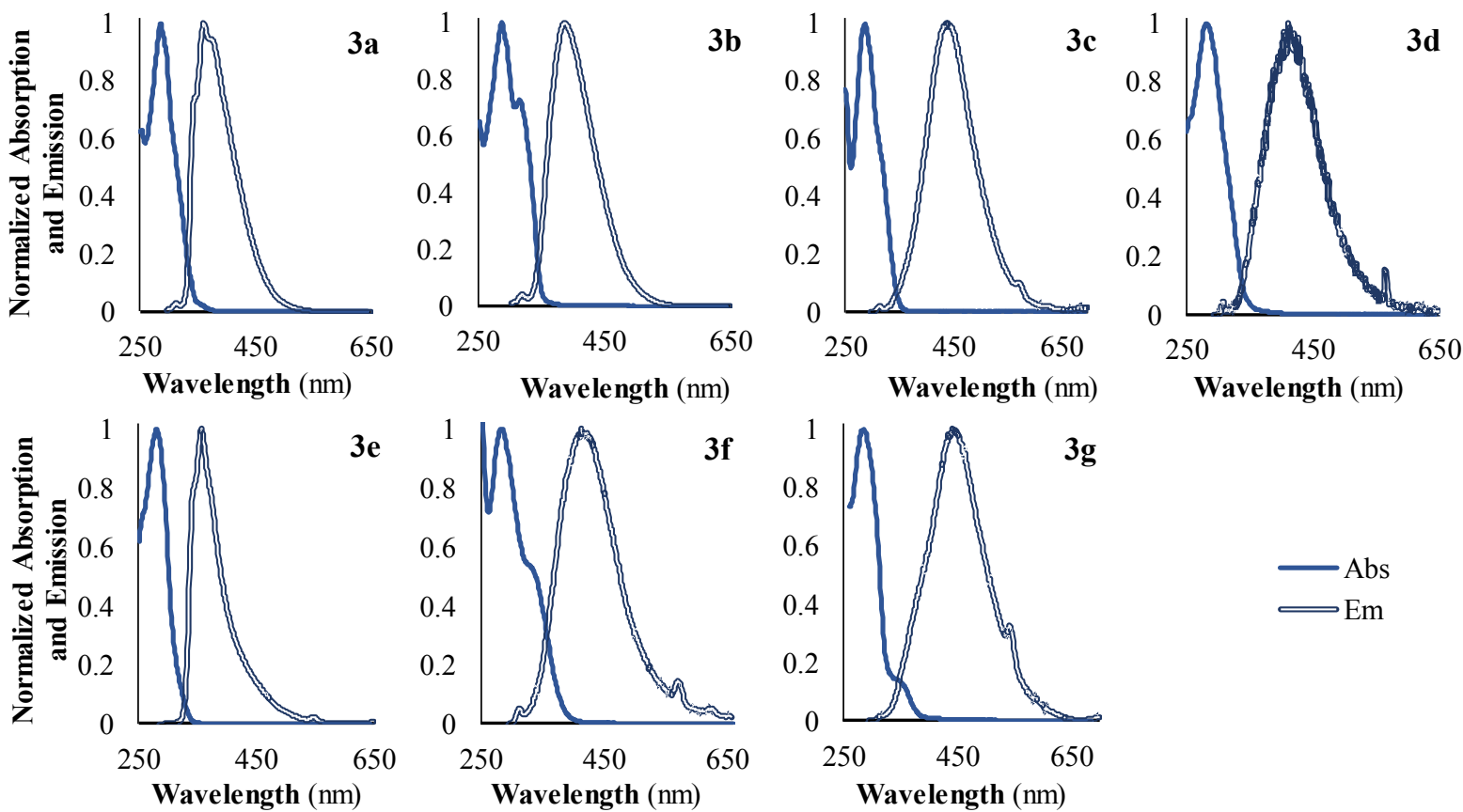

Fig. 1. Normalized absorption and emission spectra for terpyridine derivatives 3a-g, in ethanol.

the examined complexes. These peaks generally exhibit an asymmetric shape and in some cases $(\mathbf{5 b}, \mathbf{5 c}$, and $\mathbf{5 g}$ ) a shoulder can be observed, confirming that, bands corresponding to the two isomers are overlapped.

\subsection{Study of the optical properties}

The UV-Vis spectra of terpyridines $\mathbf{3}$ in ethanol at room temperature are provided in Fig. 1. All compounds exhibit a strong band of absorption between 272 and $292 \mathrm{~nm}$ that could be assigned to $\pi-\pi^{*}$ transitions of the terpyridine part [32]. Analysis of the UV-vis data of the ligands suggest that the wavelength of maximum absorption is dependant of the electron donating ability of the (hetero)aromatic groups linked at 4'-position of the terpyridine system, as well as of its $\pi$ conjugated length. Ligands $\mathbf{3 d}$ and $\mathbf{3 e}$ exhibit the shortest wavelengths of absorption maxima, indicating the weaker relative electron donating strength of the groups linked in $4^{\prime}$-position of the terpyridine moiety. Ligands $\mathbf{3 b}$ and $\mathbf{3 f}$ display the longest absorption wavelengths (with exception of $\mathbf{3 g}$ ) corresponding to the terpyridines functionalized with donor groups with stronger electron donor abilities. On the other hand, ligand $3 g$ exhibits the longer wavelength of maximum absorption due to the longer $\pi$-conjugation length of the carbazole heterocycle.

The three last aforementioned compounds, with the longest wavelengths of maximum absorption, (3b, $\mathbf{3 f}$ and $\mathbf{3 g}$ ) also exhibit lower energy shoulders in the absorption spectra $(319,330$ and $348 \mathrm{~nm}$, respectively), that seem to be due to contributions from both parts of the conjugated system, and could be ascribed to ICT process [32].

Ligands 3 were excited at the wavelength of maximum absorption, at room temperature, in order to study their fluorescence properties (Fig. 1). Ligands $\mathbf{3 d}$ and $\mathbf{3 f}$ show weak emissive properties, with relative fluorescence quantum yields of 0.06 and 0.09 , respectively, while ligands $3 \mathbf{c}, 3 \mathbf{e}$ and $\mathbf{3 g}$ exhibit moderate relative quantum yields of fluorescence in the range of $0.21-0.27$. The strongest emissive properties were observed for ligands $\mathbf{3} \mathbf{a}$ and $\mathbf{3} \mathbf{b}$, bearing a thiophene donor moieties, which exhibit relative fluorescence quantum yields of 0.59 and 0.55 , respectively.

For complexes $\mathbf{5}$, the absorbance and emission data were obtained using DMF as solvent due to their very poor solubility in other solvents. The absorbance of DMF was found to rapidly increase below $300 \mathrm{~nm}$, thus preventing a safe evaluation of the molar extinction coefficient for the ligand-centred $\pi-\pi^{*}$ bands. Values for these peaks are estimated to be in the range $28,000-35,000 \mathrm{M}^{-1} \mathrm{~cm}^{-1}$, with the only exception of $5 \mathrm{~g}$ that appears to have a higher $\varepsilon$ (up to $45,000 \mathrm{M}^{-1} \mathrm{~cm}^{-1}$ ). The spectra for all complexes (Fig. 2) present very broad absorption bands in the 550-600 nm region, possibly formed by the superposition of different MLCT bands, as already observed in analogous complexes [3c,31a]. This region appears as a broad plateau or as a large band with a maximum close to $540 \mathrm{~nm}$ and a shoulder at approximately $600 \mathrm{~nm}$, with molar extinction coefficients ranging between 7700 and 8900 $\mathrm{M}^{-1} \mathrm{~cm}^{-1}$. Another common feature is the presence of a MLCT band at about $400 \mathrm{~nm}[3 \mathrm{c}, 31 \mathrm{a}]$, often appearing as a shoulder of the most blueshifted $\pi-\pi^{*}$ transition bands. Complexes $\mathbf{5 f}$ and $\mathbf{5 g}$ display blue-shifted (about $370 \mathrm{~nm}$ ) and more intense bands, which cannot be ascribed for certain to MLCT transitions, as they could be obscured by absorptions due to ligand-centred transitions (e.g. CT transitions involving electronrich aromatic amines and electron-poor pyridine ring coordinated to $\left.\mathrm{Ru}^{\mathrm{II}}\right)$.

When complexes 5 were excited within the broad MLCT absorption band (540-600 nm) at $298 \mathrm{~K}$ in an air-equilibrated DMF solution, they exhibited an emission band at about $815 \mathrm{~nm}$ (Fig. 2, Table 3). The luminescence spectral profile is independent of excitation wavelength, and the excitation spectrum matches well with the absorption spectrum. Similar emission spectra for analogous $\left[\mathrm{Ru}^{\mathrm{II}}(\mathrm{tpy})(\mathrm{NCS})_{3}\right]^{-}$complexes have been previously reported in literature [3c,33]. Under the same experimental conditions, all the complexes emit almost at the same wavelength, suggesting that the electron-donor substituents appended on the terpyridine backbone have a very slight influence on the energy of the luminescence process. Moreover, emission bands display moderately different emission intensities, $\mathbf{5} \mathbf{b}, \mathbf{5 a}$, and $\mathbf{5 d}$ being the complexes that show the more intense relative emission.

\subsection{Electrochemical study}

The terpyridine ligands 3 were studied by cyclic voltammetry (CV), in order to evaluate their redox properties. All the examined tpy derivatives undergo a reversible or quasi-reversible reduction process at potential values between $-1.64 \mathrm{~V}$ and $-1.79 \mathrm{~V} v s$ NHE, as expected on the basis of previous investigations on different tpy derivatives [34]. 

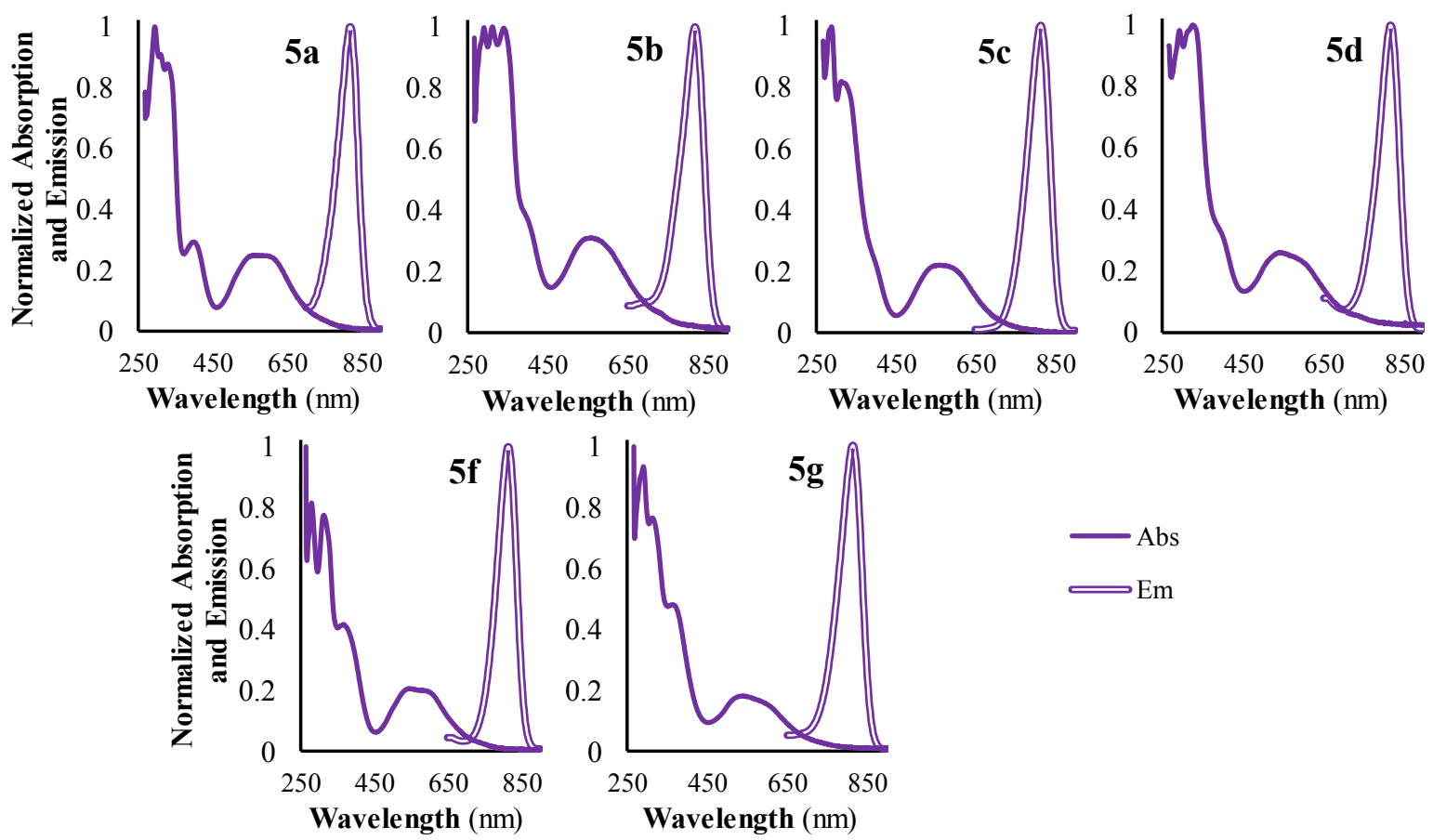

Fig. 2. Normalized absorbance and emission spectra for $\mathrm{Ru}^{\mathrm{II}}$ complexes $\mathbf{5}$, in DMF.

Table 3

Yields, absorption and emission data for $\mathrm{Ru}^{\mathrm{II}}$ complexes $\mathbf{5}$, in DMF.

\begin{tabular}{|c|c|c|c|c|c|c|}
\hline \multirow[t]{2}{*}{ Complex } & \multirow[t]{2}{*}{$\eta(\%)$} & \multicolumn{3}{|l|}{ UV-Vis } & \multicolumn{2}{|c|}{ Fluorescence } \\
\hline & & $\begin{array}{l}\lambda_{\max } \pi- \\
\pi^{*}(\mathrm{~nm})\end{array}$ & $\begin{array}{l}\lambda_{\max } \text { MLCT } \\
(\mathrm{nm})\end{array}$ & $\begin{array}{l}\varepsilon \text { MLCT } \\
\left(\mathrm{M}^{-1} \mathrm{~cm}^{-1}\right)\end{array}$ & $\begin{array}{l}\lambda_{\mathrm{em}}{ }^{\mathrm{a}} \\
(\mathrm{nm})\end{array}$ & Intensity ${ }^{\mathrm{a}, \mathrm{b}}$ \\
\hline $5 \mathbf{a}$ & 50 & $\begin{array}{l}325, \\
305, \\
290\end{array}$ & $\begin{array}{l}600-550^{c} \\
395\end{array}$ & $\begin{array}{l}8700 \\
10,300\end{array}$ & 818 & 0.32 \\
\hline $5 b$ & 34 & $\begin{array}{l}340, \\
310, \\
290\end{array}$ & $\begin{array}{l}575-545^{c} \\
400^{d}\end{array}$ & $\begin{array}{l}8900 \\
10,500\end{array}$ & 818 & 0.26 \\
\hline $5 c$ & 56 & $\begin{array}{l}310 \\
285\end{array}$ & $\begin{array}{l}580-545^{c} \\
400^{d}\end{array}$ & $\begin{array}{l}8000 \\
8000\end{array}$ & 815 & 0.98 \\
\hline $5 d$ & 59 & $\begin{array}{l}325 \\
290\end{array}$ & $\begin{array}{l}610^{\mathrm{d}} \\
540 \\
400^{\mathrm{d}}\end{array}$ & $\begin{array}{l}8200 \\
8600 \\
17,800\end{array}$ & 818 & 0.48 \\
\hline $5 f$ & 52 & $\begin{array}{l}315 \\
280\end{array}$ & $\begin{array}{l}600^{\mathrm{d}} \\
550 \\
370\end{array}$ & $\begin{array}{l}8200 \\
8600 \\
17,800\end{array}$ & 815 & 1.00 \\
\hline $5 g$ & 46 & $\begin{array}{l}310 \\
290\end{array}$ & $\begin{array}{l}610^{\mathrm{d}} \\
535 \\
365\end{array}$ & $\begin{array}{l}7000 \\
8600 \\
23,000\end{array}$ & 815 & 0.80 \\
\hline
\end{tabular}

${ }^{\text {a }}$ Due to the excessive noise a data smoothing algorithm was used to obtain the reported values.

${ }^{\mathrm{b}}$ Intensities relative to the highest recorded value among the prepared complexes.

${ }^{c}$ Instead of a well-defined maximum, a very broad plateau is observed.

${ }^{\mathrm{d}}$ Appears as a shoulder of a more intense band.

In particular, terpyridines bearing electron rich substituents (3c, $\mathbf{3 f}$, and $\mathbf{3 g}$ ) show potentials remarkably lower than the other considered ligands. Compounds $\mathbf{3 f}$ and $\mathbf{3 g}$ also undergo redox process at positive potential values, attributable to the oxidation of the aromatic amine moieties (Table 4).

Cyclic voltammetry was also used to investigate the redox behaviour of the $\mathrm{Ru}^{\mathrm{II}}$ complexes. The $\mathrm{E}_{1 / 2}$ values corresponding to $\mathrm{Ru}^{\mathrm{II} / \mathrm{III}}$ couple fall between $0.73 \mathrm{~V}$ and $0.77 \mathrm{~V}$ vs NHE, in agreement with previous electrochemical studies carried out on analogous complexes [3c]. Potential values ascribed to the ligand-centred reduction processes are distinctly less negative (between -1.27 and $-1.33 \mathrm{~V}$ ) than
Table 4

Electrochemical data for the terpyridine derivatives 3 in DMF.

\begin{tabular}{lll}
\hline \multirow{2}{*}{ Cpds } & \multicolumn{2}{l}{$\mathrm{V} v s$ NHE $(\mathrm{V})$} \\
\cline { 2 - 3 } & $\mathrm{E}_{1 / 2}\left(3 / 3^{+}\right)$ & $\mathrm{E}_{1 / 2}\left(3 / 3^{-}\right)$ \\
\hline $\mathbf{3 a}$ & - & -1.64 \\
$\mathbf{3 b}$ & - & -1.68 \\
$\mathbf{3 c}$ & - & -1.77 \\
$\mathbf{3 d}$ & - & -1.69 \\
$\mathbf{3 e}$ & - & -1.67 \\
$\mathbf{3 f}$ & 1.07 & -1.77 \\
$\mathbf{3 g}$ & $1.58^{\mathrm{a}}$ & -1.79 \\
\hline
\end{tabular}

${ }^{\text {a }}$ Value referred to $\mathrm{E}_{\mathrm{p}}$. Not reversible process: only the oxidation peak is observed in the CV profile.

Table 5

Electrochemical data for $\mathrm{Ru}^{\mathrm{II}}$ complexes $\mathbf{5}$ in DMF.

\begin{tabular}{llll}
\hline \multirow{2}{*}{ Cpds } & \multicolumn{2}{l}{$\mathrm{V} v s$ NHE $(\mathrm{V})$} & \\
\cline { 2 - 4 } & $\mathrm{E}_{1 / 2} \mathrm{Ru}^{\mathrm{II} / \mathrm{III}}$ & $\mathrm{E}_{1 / 2}$ tpy/tpy & Others \\
\hline $\mathbf{5 a}$ & 0.77 & -1.25 & - \\
$\mathbf{5 b}$ & 0.76 & -1.25 & - \\
$\mathbf{5 c}$ & 0.73 & -1.33 & - \\
$\mathbf{5 d}$ & 0.77 & -1.29 & - \\
$\mathbf{5 f}$ & 0.77 & -1.30 & $1.54^{\mathrm{a}}, 1.42^{\mathrm{a}}, 1.13,-0.15$ \\
$\mathbf{5 g}$ & 0.74 & -1.33 & $1.76^{\mathrm{a}}$ \\
\hline
\end{tabular}

${ }^{\text {a }}$ Value referred to $\mathrm{E}_{\mathrm{p}}$. Not reversible process: only the oxidation peak is observed in the CV profile.

the corresponding values determined for compounds 3 , as expected due to the positive charge of the metal ion (Table 5).

The most negative potential values were obtained for complexes $\mathbf{5 g}$, $\mathbf{5 c}$, and $\mathbf{5 f}$, similarly to what observed for the corresponding free ligands (3g, 3c, and $\mathbf{3 f}$ ). It indicates that in the CV experimental conditions these functionalized terpy derivatives exhibit the strongest electron-donor behaviour among the investigated ones, and disfavour to an higher extent the reduction process. Complex $\mathbf{5 g}$ undergoes an additional irreversible oxidation process at $1.76 \mathrm{~V}$, which is attributed to the 
oxidation of the aromatic amine substituent, taking place at higher potential value than the corresponding uncomplexed ligand $\mathbf{3 g}$. Complex $\mathbf{5 f}$ presents additional signals, both at negative and positive potentials; in particular, three close peaks observed between 1.1 and $1.6 \mathrm{~V}$ can be ascribed to the oxidation of $\mathrm{N}, \mathrm{N}$-dimethylnaphthalen-1amine moiety taking place at higher potential values if compared to ligand 3f. In some experiments, a small irreversible signal was observed at approximately $-0.9 \mathrm{~V}$, after occasional exposure to atmospheric humidity occurring during the preparation of the complex solutions, while it was absent in CV profile obtained in pure $\mathrm{DMF} /\left[\mathrm{Bu}_{4} \mathrm{~N}\right] \mathrm{PF}_{6}$.

The range in which the ruthenium oxidation potentials are distributed is very narrow and most complexes present the same oxidation potential, with $\mathbf{5 c}$ and $\mathbf{5 g}$ complexes displaying the lowest values of the sequence. The presence of conjugated electron rich substituents (particularly $\mathbf{3 c}$ and $\mathbf{3 g}$ ), as expected, stabilizes the oxidized $\mathrm{Ru}^{\mathrm{III}}$ species, in addition to destabilizing the reduced ligand, as mentioned above.

\subsection{Nonlinear optical properties}

The molecular first hyperpolarizabilities $\beta$ of terpyridine derivatives 3 were obtained by hyper-Rayleigh scattering (HRS) technique [35] at a fundamental wavelength of $1064 \mathrm{~nm}$ of a laser beam. Dioxane was used as the solvent, and the $\beta$ values were measured against a reference solution of $p$-nitroaniline ( $p$ NA) [36] in order to obtain quantitative values, while care was taken to properly account for possible fluorescence of the dyes (see experimental section for more details). The static hyperpolarizability $\beta_{0}$ values [37] were calculated using a very simple two-level model neglecting damping. They are therefore only indicative and should be treated with caution (Table 6).

It is clear that the electronic donor ability and the increase of the $\pi$ conjugation of the groups substituted in $4^{\prime}$-position of the terpyridine system, have a clear influence on the nonlinearities $\beta$ of compounds 3 . Therefore, 9-ethyl-9H-carbazolyl moiety being an electron rich moiety, and the highest conjugated group, gives rise to a higher hyperpolarizability for compound $3 \mathrm{~g}\left(\beta=610 \times 10^{-30} \mathrm{esu}\right)$, compared to the other push-pull terpyridine derivatives 3 . As expected, other terpyridine derivatives functionalized with stronger electron donor groups and/or higher conjugated moieties exhibit higher $\beta$ values (e.g. 3d and 3f) compared to the other derivatives. On the other hand, comparison of the $\beta$ values for $3 \mathbf{d}\left(\beta=216 \times 10^{-30}\right.$ esu $)$ and $3 \mathbf{e}$ $\left(\beta=180 \times 10^{-30} \mathrm{esu}\right)$ showed that the substitution of the electrondeficient imidazole heterocycle on the $\pi$-bridge by the electron-rich pyrrole leads to larger values of the molecular hyperpolarizability $\beta$ while maintaining the same electron-acceptor terpyridine group. Also noteworthy is the difference in the second order nonlinear response of compounds 3a $\left(\beta=80 \times 10^{-30} \mathrm{esu}\right)$ and $\mathbf{3 b}\left(\beta=185 \times 10^{-30} \mathrm{esu}\right)$ which differ solely by the addition of an alkyl chain in the latter. We

Table 6

UV-visible absorption, $\beta$ values, $\beta_{0}$ values for $p$ NA and for terpyridine derivatives 3 .

\begin{tabular}{llll}
\hline Cpds & $\lambda_{\max }(\mathrm{nm})$ & $\beta^{\mathrm{b}}\left(10^{-30} \mathrm{esu}\right)$ & $\beta_{0}{ }^{\mathrm{c}}\left(10^{-30} \mathrm{esu}\right)$ \\
\hline 3a & 286 & 80 & 53 \\
3b & 287 & 185 & 120 \\
3c & 285 & $\mathrm{~d}$ & - \\
3d & 286 & 216 & 140 \\
3e & 285 & 180 & 120 \\
3f & 287 & 215 & 141 \\
3g & 296 & 610 & 390 \\
pNA & 352 & 40.1 & -
\end{tabular}

${ }^{\text {a }}$ Experimental first hyperpolarizabilities $\beta$ and spectroscopic data measured in dioxane solutions.

${ }^{\mathrm{b}}$ All compounds are transparent at the $1064 \mathrm{~nm}$ fundamental wavelength and the hyperpolarizability values are reported using the T-convention.

${ }^{c}$ Data corrected for resonance enhancement at $532 \mathrm{~nm}$ using the two-level model with $\beta_{0}=\beta\left[1-\left(\lambda_{\max } / 1064\right)^{2}\right]\left[1-\left(\lambda_{\max } / 532\right)^{2}\right]$; damping factors not included $1064 \mathrm{~nm}$.

${ }^{\mathrm{d}}$ Due to overlapping fluorescence it was not possible to measure the $\beta$ value.
Table 7

UV-visible absorption, $\beta$ values, $\beta_{0}$ values for $p$ NA and for terpyridine derivative $3 \mathbf{c}$ and $\mathrm{Ru}^{\mathrm{II}}$ complexe $5 \mathrm{c}^{\mathrm{a}}$

\begin{tabular}{llll}
\hline Cpds & $\lambda_{\max }(\mathrm{nm})$ & $\beta^{\mathrm{b}}\left(10^{-30} \mathrm{esu}\right)$ & $\beta_{0}{ }^{\mathrm{c}}\left(10^{-30} \mathrm{esu}\right)$ \\
\hline 3c & 286 & 153 & 102 \\
$\mathbf{5 c}$ & 283,317 & 50 & 30 \\
pNA & 370 & 62 & 28 \\
\hline
\end{tabular}

${ }^{a}$ Experimental first hyperpolarizabilities $\beta$ and spectroscopic data measured in methanol solutions.

${ }^{\mathrm{b}}$ All compounds are transparent at the $1064 \mathrm{~nm}$ fundamental wavelength and the hyperpolarizability values are reported using the T-convention.

${ }^{\mathrm{c}}$ Data corrected for resonance enhancement at $532 \mathrm{~nm}$ using the two-level model with $\beta_{0}=\beta\left[1-\left(\lambda_{\max } / 1064\right)^{2}\right]\left[1-\left(\lambda_{\max } / 532\right)^{2}\right]$; damping factors not included $1064 \mathrm{~nm}$.

speculate that the alkyl chain serves as an electron donor, allowing more charge to be concentrated on the thiophene ring in the HOMO. However, the size of the effect is rather surprising and it would be interesting to explore this point by performing DFT calculations.

Attempts were made in order to measure the first hyperpolarizabilities $\beta$ for complexes 5 in methanol solutions [36] due to their insolubility in dioxane. Nevertheless, due to strong overlapping fluorescence, it was only possible to obtain reliable results for complex $\mathbf{5 c}$. In order to compare the effect of the complexation on the $\beta$ values for terpyridine derivatives, the study of SHG for ligand $3 \mathbf{c}$ was also performed in methanol solution. Therefore, comparison of the $\beta$ values for terpyridine ligand $3 \mathbf{c}\left(\beta=153 \times 10^{-30} \mathrm{esu}\right)$ and $\mathbf{5 c}$ $\left(\beta=50 \times 10^{-30}\right.$ esu) showed that the corresponding $\mathrm{Ru}^{\mathrm{II}}$ complex exhibits a lower value of the molecular hyperpolarizability $\beta$ (Table 7), which is in agreement with previous findings concerning terpyridines complexes [5b-h]. Our reported value for compound $\mathbf{5 c}$ might be artificially lower due to the MLCT absorption band that overlaps with the second harmonic wavelength at $532 \mathrm{~nm}$.

\section{Conclusions}

Starting from commercially available precursors as well as by using simple and convenient procedures, several push-pull terpyridines $\mathbf{3}$ were obtained in fair to good yields by Kröhnke condensation. Terpyridine derivatives $\mathbf{3}$ were also used as ligands for the synthesis of novel $\left[\mathrm{Ru}^{\mathrm{II}}(3)(\mathrm{NCS})_{3}\right]^{-}$complexes 5 , which display a broad and intense absorption in the visible range, and they have been isolated as a mixture of two main isomers due to the ambidentate nature of $\mathrm{SCN}^{-} .{ }^{1} \mathrm{H}$ NMR and FTIR-ATR studies suggested that isomer containing all Nbound thiocyanate ligands is the most abundant. The electrochemical and, linear and nonlinear optical properties of these organic and organometallic $\pi$-conjugated systems can be readily tuned by varying the electron donating character of the (hetero)aromatic subunit linked to the electron-deficient terpyridine system in compounds $\mathbf{3}$, as well as in the corresponding $\mathrm{Ru}^{\mathrm{II}}$ complexes $\mathbf{5}$.

Hyper-Rayleigh scattering was used to determine the first hyperpolarizability, $\beta$, of terpyridines 3 . Optical and electrochemical properties for compounds $\mathbf{3}$ indicate that, they could be candidates as novel second order nonlinear optical chromophores.

\section{Experimental}

\subsection{Materials and methods}

All commercially available reagents and solvents were used as received. Reaction progress was monitored by thin layer chromatography, $0.25 \mathrm{~mm}$ thick precoated silica plates (Merck Fertigplatten Kieselgel 60 F254), and spots were visualised under UV light. Melting points were determined on a Gallenkamp apparatus and are uncorrected. NMR spectra of the ligands were obtained on a Brucker Avance II 400 at an operating frequency of $400 \mathrm{MHz}$ for ${ }^{1} \mathrm{H}$ and 
100.6 $\mathrm{MHz}$ for ${ }^{13} \mathrm{C}$, using the solvent peak as internal reference. The solvents are indicated in parenthesis before the chemical shifts values ( $\delta$ relative to TMS). Peak assignments were made by comparison of chemical shifts, peak multiplicities and $J$ values, and were supported by spin decoupling-double resonance and bidimensional heteronuclear HMBC (heteronuclear multiple bond coherence) and HMQC (heteronuclear multiple quantum coherence) techniques. NMR spectra of the complexes were obtained on a Bruker Avance 400 spectrometer (400 MHz) operating at $9.37 \mathrm{~T}$, located at Centro Grandi Strumenti, University of Pavia. Infrared spectra of ligands were recorded by a BOMEM MB 104 spectrophotometer. Infrared spectra of complexes were obtained by a Perkin Elmer Spectrum 100 FT-IR spectrometer equipped with a UATR accessory. UV-vis absorption spectra of the ligands were obtained using a Shimadzu UV/2501PC spectrophotometer. UV-Vis absorption spectra of the complexes were recorded on a Varian Cary 50 spectrophotometer, using DMF as solvent. Emission spectra of the ligands were collected using a FluoroMax-4 spectrofluorometer. Fluorescence quantum yields were measured in comparison with a solution of quinine sulphate in $0.05 \mathrm{M} \mathrm{H}_{2} \mathrm{SO}_{4}$ as standard and corrected for the refraction index of the solvents [38]. Emission spectra of the complexes were recorded on a Varian Cary Eclipse fluorimeter, using DMF as solvent. Mass spectrometry analysis were performed at the C.A.C.T.I. - Unidad de Espectrometria de Masas of the University of Vigo, Spain.

\subsection{Synthesis}

\subsubsection{General procedure for the synthesis of terpyridine ligands 3 through} Kröhnke condensation

2-Acetylpyridine 2 ( $3 \mathrm{~mol}$ ) was added to a solution of the appropriate aldehyde 1a-g $(1.5 \mathrm{~mol})$ in ethanol $(20 \mathrm{~mL})$. Potassium hydroxide pellets $(3.6 \mathrm{~mol})$, and $25 \%$ aqueous ammonia $(15 \mathrm{~mL})$ were then added to the solution. The mixture was stirred at room temperature for $72 \mathrm{~h}$. The resultant precipitate was filtered, washed with ice cold $50 \%$ aqueous ethanol and dried under reduced pressure to give the pure compounds 3a-g.

4.2.1.1. 2-(6'-(Pyridin-2"-yl)-4'-(thiophen-2"'-yl)pyridin-2'-yl)pyridine, $3 \boldsymbol{a}$ [28]. Green solid (53\%). Mp: 197-199 ${ }^{\circ} \mathrm{C}$. IR (liquid film) $\nu 3057$, 3011, 1598, 1564, 1547, 1463, 1444, 1360, 1389, 1264, 1232, 1148, 1121, 1091, 1091, 1043, 1010, 985, 885, 832, 788, 771, 734, 704, $679 \mathrm{~cm}-1 \lambda_{\max }\left(\right.$ ethanol) $/ \mathrm{nm} 286\left(\varepsilon / \mathrm{M}^{-1} \mathrm{~cm}^{-1} 25,778\right) .{ }^{1} \mathrm{H}$ NMR (400 MHz, DMSO-d $\left.d_{6}\right) \delta 7.25$ (dd, $1 \mathrm{H}, J=5.4$ and $3.6 \mathrm{~Hz}, \mathrm{H}-4^{\prime \prime \prime}$ ), 7.50-7.54 (m, 2H, H-5, H-5"), 7.79 (d, $1 \mathrm{H}, J=5.2 \mathrm{~Hz}, \mathrm{H}-3^{\prime \prime \prime}$ ), 7.94 (d, $\left.1 \mathrm{H}, J=5.2 \mathrm{~Hz}, \mathrm{H}-5^{\prime \prime \prime}\right), 8.00-8.05$ (m, 2H, H-4, H-4"), 8.62-8.65 (m, $4 \mathrm{H}, \mathrm{H}-3, \mathrm{H}-3^{\prime \prime}, \mathrm{H}-3^{\prime}, \mathrm{H}-5^{\prime}$ ), 8.75-8.77 (m, 2H, H-6, H-6") ppm.

\subsubsection{2-(4'-(5"-hexylthiophen-2"'-yl)-6'-(pyridin-2'"'-yl)pyridin-2'-yl)} pyridine, $3 \boldsymbol{b}$. Beije solid (20\%). Mp: 70-72 ${ }^{\circ} \mathrm{C}$. IR (liquid film) $\nu 3380$, 3055, 3013, 2926, 2855, 2683, 2304, 1984, 1957, 1858, 1756, 1733, $1696,1599,1583,1566,1552,1468,1437,1398,1377,1340,1265$, $1233,1201,1147,1125,1092,1077,1058,1043,990,965,847 \mathrm{~cm}-1$ $\lambda_{\max }$ (ethanol)/nm $292\left(\varepsilon / \mathrm{M}^{-1} \mathrm{~cm}^{-1} 29,333\right) .{ }^{1} \mathrm{H}$ NMR $(400 \mathrm{MHz}$, DMSO-d $\left.d_{6}\right) \quad \delta .84\left(\mathrm{t}, 3 \mathrm{H}, \mathrm{CH}_{3}\right), 1.24-1.35\left(\mathrm{~m}, 6 \mathrm{H},\left(\mathrm{CH}_{2}\right)_{3} \mathrm{CH}_{3}\right)$, 1.61-1.68 (m, $\left.2 \mathrm{H}, \mathrm{CH}_{2}\left(\mathrm{CH}_{2}\right)_{3} \mathrm{CH}_{3}\right), 2.81\left(\mathrm{t}, 2 \mathrm{H}, \mathrm{CH}_{2}\left(\mathrm{CH}_{2}\right)_{4} \mathrm{CH}_{3}\right), 6.95$ (d, $1 \mathrm{H}, J=3.6 \mathrm{~Hz}, \mathrm{H}-4^{\prime \prime}$ ), 7.49-7.52 (m, 2H, H-5, H-5"'), 7.73 (d, 1H, $J=3.6 \mathrm{~Hz}, \mathrm{H}-3^{\prime \prime}$ ), 7.98-8.03 (m, 2H, H-4, H-4"'), 8.56 (s, 2H, H-3', H$5^{\prime}$ ), 8.60 (d, $\left.2 \mathrm{H}, J=8.0 \mathrm{~Hz}, \mathrm{H}-3, \mathrm{H}-3^{\prime \prime \prime}\right), 8.73-8.75$ (m, 2H, H-6, H-6"') ppm. ${ }^{13} \mathrm{C}$ NMR (100.6 MHz, DMSO- $\left.d_{6}\right) \delta 13.9,22.0,28.1,29.5,30.9$, $30.9,115.5,120.9,124.6,126.5,137.4,137.8,142.9,148.2,149.3$, 154.8, 155.7 ppm. MS (EI) $m / z(\%)=399\left([\mathrm{M}]^{+}, 24\right), 328(100)$. HRMS: $m / z$ (EI) for $\mathrm{C}_{25} \mathrm{H}_{25} \mathrm{~N}_{3} \mathrm{~S}$; calcd 399.1769; found: 399.1772 .

4.2.1.3. 2-(4'-(3",4"-dimethoxyphenyl)-6'-(pyridin-2"'-yl)pyridin-2'-yl) pyridine, 3c $[28 b, 29]$. Light brown solid (55\%). Mp: 77-77 ${ }^{\circ} \mathrm{C}$. IR (liquid film) $\nu$ 3400, 2992, 2929, 2898, 2830, 2355, 1602, 1584, 1520,
$1468,1391,1322,1260,1207,1166,1147,1077,1024,990,885,851$, 786, 762, $730 \mathrm{~cm}-1 \lambda_{\max }$ (ethanol)/nm $286\left(\varepsilon / \mathrm{M}^{-1} \mathrm{~cm}^{-1} 24,083\right) .{ }^{1} \mathrm{H}$ NMR (400 MHz, DMSO-d $\left.d_{6}\right) \delta 3.83\left(\mathrm{t}, 3 \mathrm{H}, \mathrm{OCH}_{3}\right), 3.90\left(\mathrm{t}, 3 \mathrm{H}, \mathrm{OCH}_{3}\right.$ ), 7.12 (d, $1 \mathrm{H}, J=8.4 \mathrm{~Hz}, \mathrm{H}-3^{\prime \prime}$ ), 7.41-7.52 (m, 4H, H-5, H-5"', H-2", H$6^{\prime \prime}$ ), 7.99-8.04 (m, 2H, H-4, H-4"'), 8.62-8.64 (m, 4H, H-3', H-5', H-3, $\left.\mathrm{H}-3^{\prime \prime \prime}\right), 8.74-8.76\left(\mathrm{~m}, 2 \mathrm{H}, \mathrm{H}-6, \mathrm{H}-6^{\prime \prime \prime}\right)$ ppm. ${ }^{13} \mathrm{C}$ NMR $(100.6 \mathrm{MHz}$, DMSO- $\left.d_{6}\right) \delta 55.6,55.8,110.1,112.2,117.6,119.7,120.9,124.5,137.4$, $149.3,149.5,150.1,155.1,155.5$ ppm.

4.2.1.4. 2-(4'-(4"-(1H-pyrrol-1"'-yl)phenyl)-6'-(pyridin-2'"-yl)pyridin-2'yl)pyridine, 3d. Brown solid (26\%). Mp: dec $>200{ }^{\circ} \mathrm{C}$. IR (liquid film) $\nu$ 3145, 3012, 1609, 1586, 1566, 1529, 1425, 1390, 1334, 1266, 1120, 1069, 991, 897, $828 \mathrm{~cm}-1 \lambda_{\max }$ (ethanol)/nm $283\left(\varepsilon / \mathrm{M}^{-1} \mathrm{~cm}^{-1}\right.$ 22,675). ${ }^{1} \mathrm{H}$ NMR (400 MHz, DMSO- $\left.d_{6}\right) \delta 6.31$ (d, $2 \mathrm{H}, J=4.4 \mathrm{~Hz}, \mathrm{H}-$ 2"', H-5"'), 7.48-7.54 (m, 4H, H-5, H-5"'”, H-3"', H-4"'), 7.78 (d, 2H, $J=7.2 \mathrm{~Hz}, \mathrm{H}-3^{\prime \prime}, \mathrm{H}-5^{\prime \prime}$ ), 8.00-8.06 (m, 4H, H-4, H-4"'”, H-2", H-6"), 8.65 (d, 2H, H-3, H-3'"''), 8.76 (s, 2H, H-3', H-5'), 8.76-8.77 (m, 2H, H6, H-6"') ppm. ${ }^{13} \mathrm{C}$ NMR (100.6 MHz, DMSO- $\left.d_{6}\right) \delta 110.9,117.6,118.9$, $119.8,120.9,124.5,128.3,134.0,137.5,140.7,148.6,149.3,154.9$, 155.7 ppm. MS (EI) $m / z(\%)=374\left([\mathrm{M}]^{+}, 100\right), 296$ (14). HRMS: $m / z$ (EI) for $\mathrm{C}_{25} \mathrm{H}_{18} \mathrm{~N}_{4}$; calcd 374.1531; found: 374.1534.

4.2.1.5. 2-(4'-(4"-(1h-imidazole-1"'-yl)phenyl)-6'-(pyridin-2"'-yl)pyridin$2^{\prime}$-yl)pyridine, $3 \boldsymbol{e}$ [30]. Brown solid (69\%). Mp: $210-212{ }^{\circ} \mathrm{C}$. IR (liquid

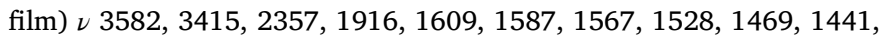
1425, 1392, 1331, 1309, 1264, 1200, 1148, 1119, 1076, 1059, 992, 962, 903, $888 \mathrm{~cm}-1 \lambda_{\max }$ (ethanol)/nm $274\left(\varepsilon / \mathrm{M}^{-1} \mathrm{~cm}^{-1} 65,261\right) .{ }^{1} \mathrm{H}$ NMR (400 MHz, DMSO- $d_{6}$ ) $\delta$ 7.15-7.16 (m, 1H, H-4"'), 7.49-7.52 (m, 2H, H-5, H-5'"') $)$ 7.83-7.85 (m, 3H, H-5'"', H-3", H-5'), 7.99-8.04 (m, 4H, H-4, H-4"'", H-2", H-6"), 8.36-8.37 (m, 1H, H-2"'), 8.62 (d, 2H, $J=8.0 \mathrm{~Hz}, \mathrm{H}-3, \mathrm{H}-3^{\prime \prime \prime}$ )', 8.69 (s, 2H, H-3', H-5'), 8.73-8.75 (m, 2H, H-6, H-6"'”) ppm. ${ }^{13} \mathrm{C}$ NMR (100.6 MHz, DMSO- $\left.d_{6}\right) \delta 117.8,117.9,120.9$, 121.1 , 124.6, 128.5, 130.2, 135.6, 135.8, 137.5, 137.7, 148.4, 149.4, 154.9, $155.8 \mathrm{ppm}$.

4.2.1.6. $N, N$-dimethyl-4-(2',6'-di(pyridin-2"-yl)pyridin-4'-yl)naphthalen1-amine, 3f. Beije solid (33\%). Mp: $165-167^{\circ} \mathrm{C}$. IR (liquid film) $\nu 3058$, 3004, 2940, 2869, 2834, 2787, 2308, 1986, 1959, 1921, 1892, 1857, $1731,1647,1598,1579,1565,1537,1513,1464,1443,1425,1390$, $1355,1332,1265,1200,1142,1118,1100,1064,1048,989,825 \mathrm{~cm}-1$ $\lambda_{\max }\left(\right.$ ethanol)/nm $288\left(\varepsilon / \mathrm{M}^{-1} \mathrm{~cm}^{-1} 25,258\right) .{ }^{1} \mathrm{H}$ NMR $(400 \mathrm{MHz}$, DMSO- $d_{6}$ ) $\delta 7.22$ (d, $\left.1 \mathrm{H}, J=8.0 \mathrm{~Hz}, \mathrm{H}-2\right), 7.48-7.61$ (m, $5 \mathrm{H}, 2 \times \mathrm{H}-5^{\prime \prime}$, H-7, H-6, H-3), 7.90 (d, 1H, $J=8.0 \mathrm{~Hz}, \mathrm{H}-8$ ), 8.02-8.06 (m, $2 \mathrm{H}, 2 \times \mathrm{H}-$ $4^{\prime \prime}$ ), 8.27 (d, $1 \mathrm{H}, J=8.4 \mathrm{~Hz}, \mathrm{H}-5$ ), 8.35 (s, 2H, H-5', H-3'), 8.69-8.72 (m, $4 \mathrm{H}, 2 \times \mathrm{H}-6$ ", $\left.2 \times \mathrm{H}-3^{\prime \prime}\right)$ ppm. ${ }^{13} \mathrm{C}$ NMR (100.6 MHz, DMSO-d 6 ) $\delta$ 113.6, 120.9, 121.6, 124.5, 124.7, 125.1, 125.4, 126.8, 127.4, 128.2, $131.4,131.4,137.5,149.4,150.2,151.3,154.9,155.2 \mathrm{ppm}$. MS (EI) $\mathrm{m} /$ $z(\%)=402\left([\mathrm{M}]^{+}, 100\right), 385$ (30). HRMS: $m / z$ (EI) for $\mathrm{C}_{27} \mathrm{H}_{22} \mathrm{~N}_{4}$; calcd 402.1844; found: 402.1842 .

4.2.1.7. 9-Ethyl-3-(2',6'-di(pyridin-2"-yl)pyridin-4'-yl)-9H-carbazole, $3 g$ [6i]. Beije solid (51\%). Mp: $167-169^{\circ} \mathrm{C}$. IR (liquid film) $\nu 3583$, 3053, 3016, 2977, 2935, 2896, 2685, 2519, 2305, 1928, 1884, 1695, $1662,1626,1595,1584,1567,1547,1491,1469,1439,1415,1395$, $1347,1332,1265,1234,1156,1129,1087,1037,992,792 \mathrm{~cm}-1 \lambda_{\max }$ (ethanol)/nm $272\left(\varepsilon / \mathrm{M}^{-1} \mathrm{~cm}^{-1} 63,065\right) .{ }^{1} \mathrm{H}$ NMR (400 MHz, DMSO- $\left.d_{6}\right)$ $\delta 1.33\left(\mathrm{t}, 3 \mathrm{H}, \mathrm{CH}_{3}\right), 4.46\left(\mathrm{q}, 2 \mathrm{H}, \mathrm{CH}_{2}\right), 7.23-7.27(\mathrm{~m}, 1 \mathrm{H}, \mathrm{H}-6)$, 7.47-7.54 (m, 3H, $2 \times \mathrm{H}-5$ ", H-7), 7.64 (d, $1 \mathrm{H}, J=8.0 \mathrm{~Hz}, \mathrm{H}-8)$, 7.77 (d, $1 \mathrm{H}, J=8.4 \mathrm{~Hz}, \mathrm{H}-5$ ), 8.01-8.06 (m, 3H, $2 \times \mathrm{H}-4^{\prime \prime}, \mathrm{H}-8$ ), 8.38 (d, $1 \mathrm{H}, J=7.2 \mathrm{~Hz}, \mathrm{H}-5$ ), 8.67 (d, $2 \mathrm{H}, J=8.0 \mathrm{~Hz}, 2 \times \mathrm{H}-6^{\prime \prime}$ ), 8.77-8.79 (m, 3H, $\left.2 \times \mathrm{H}-3^{\prime \prime}, \mathrm{H}-4\right), 8.83$ (s, 2H, H-3', H-5') ppm. ${ }^{13} \mathrm{C}$ NMR $\left(100.6 \mathrm{MHz}, \mathrm{DMSO}-d_{6}\right) \delta 13.8,37.2,109.4,109.9,117.9,119.1$, $119.2,120.9,121.1,122.4,123.1,124.5,124.7,126.3,128.2,137.5$, $140.1,140.2,149.3,150.5,155.3,155.6 \mathrm{ppm}$. MS (EI) $m / z(\%)=426$ $\left([\mathrm{M}]^{+}, 84\right.$ ), 411 (100). HRMS: $m / z$ (EI) for $\mathrm{C}_{29} \mathrm{H}_{22} \mathrm{~N}_{4}$; calcd 426.1844; found: 426.1843 . 
4.2.2. General procedure for the synthesis of the $\left[\mathrm{Ru}{ }^{I I I}(3) \mathrm{Cl}_{3}\right]$ intermediate complexes 4 from the respective terpyridine ligands $\mathbf{3}$

This procedure is a variation of a reported synthesis on $\left[\mathrm{Ru}^{\mathrm{III}}\right.$ (tpy) $\left.\mathrm{Cl}_{3}\right]$ complexes with terpyridine ligands [39]. The envisaged terpyridine ligand (3a-g, 1 equiv.) and ruthenium trichloride hydrate (1 equiv.) were suspended in degassed ethanol $(100 \mathrm{~mL}$ of solvent per $1 \mathrm{mmol}$ of reagent), and refluxed under nitrogen for 3.5-4.5 h. After a few hours at room temperature the suspension was filtered on a Buchner funnel. The solid was washed with abundant ethanol until the filtered liquid appears as colorless, followed with three portions of diethyl ether and dried under vacuum to give the intermediates 4 ( $\eta$ 47-79\%). The compounds were used for the next reaction step without further characterization.

\subsubsection{General procedure for the synthesis of the $\left[R u^{I I}(3)(N C S)_{3}\right]^{-}$} complexes 5 from the respective intermediates $\mathbf{4}$

This procedure is based on a reported synthesis of a $\left[\mathrm{Ru}^{\mathrm{II}}(\mathrm{tpy})\right.$ $\left.(\mathrm{NCS})_{3}\right]^{-}$complex with a terpyridine ligand [31a]. KSCN (40-45 equiv.) dissolved in water ( $0.5 \mathrm{~mL}$ per $\mathrm{mL}$ of DMF) was added to a solution of intermediate 4 (0.05-0.08 mmol) in DMF (200 mL per mmol of 4), and the reaction mixture was refluxed for $3 \mathrm{~h}$. After this time, trimethylamine (10-15 equiv.) was added to the solution, and reflux was continued for $20 \mathrm{~min}$. The solution was concentrated with a rotavapor until only a few drops of black solution were left, and water was added to afford a very fine dark violet precipitate. The suspension was dried at the rotavapor and a second portion of water was added, affording larger grains of solid. The suspension was agitated for a few minutes and then left standing for a few hours to ensure the complete dissolution of thiocyanates and chlorides. The suspension was filtered on a Buchner funnel, and the solid washed with at least three portions of water and dried under vacuum, to give the products 5 .

4.2.3.1. Complex 5a: $\mathrm{Et}_{3} \mathrm{NH}\left[\mathrm{Ru}(3 a)(\mathrm{NCS})_{3}\right]$. Black solid (69\%). ${ }^{1} \mathrm{H}$ $\mathrm{NMR}\left(400 \mathrm{MHz}, \mathrm{CD}_{3} \mathrm{CN}\right) \delta$ (main isomer, approximately $85 \%$ of the total) 1.26 (9H, t, $J=7.2 \mathrm{~Hz}$ ), $3.14(6 \mathrm{H}, \mathrm{q}, J=7.2 \mathrm{~Hz}), 7.27(1 \mathrm{H}, \mathrm{dd}, J=5.0$ and $3.8 \mathrm{~Hz}), 7.64(1 \mathrm{H}, \mathrm{d}, J=5.0 \mathrm{~Hz}), 7.69(2 \mathrm{H}, \mathrm{dd}, J=7.8$ and 5.4 $\mathrm{Hz}), 7.92(1 \mathrm{H}, \mathrm{d}, J=3.8 \mathrm{~Hz}), 8.02(2 \mathrm{H}, \mathrm{dd}, J=8.1 \mathrm{and} 7.8 \mathrm{~Hz}), 8.43$ (2H, s), $8.40(2 \mathrm{H}, \mathrm{d}, J=8.1 \mathrm{~Hz}), 8.93(2 \mathrm{H}, \mathrm{d}, J=5.4 \mathrm{~Hz})$. MS (ESI) $\mathrm{m} /$ $z(\%)=590\left([\mathrm{M}]^{+}, 100\right), 417$ (96), 403 (42), 389 (29), 255 (23). HRMS: $m / z$ (ESI) $[M]^{+}$found 590.9127; $\mathrm{C}_{22} \mathrm{H}_{13} \mathrm{~N}_{6} \mathrm{RuS}_{4}$ requires 590.9134 .

4.2.3.2. Complex 5b: $E t_{3} N H\left[R u(3 b)(N C S)_{3}\right]$. Black solid $(73 \%) .{ }^{1} \mathrm{H}$ NMR ( $400 \mathrm{MHz}, \mathrm{CD}_{3} \mathrm{CN}$ ) $\delta$ (main isomer, approximately $85 \%$ of the total) 0.95 (3H, broad), 1.26 (9H, t, $J=7.2 \mathrm{~Hz}), 1.50-1.35(8 \mathrm{H}, \mathrm{m}), 2.96$ $(2 \mathrm{H}, \mathrm{t}, J=5.3 \mathrm{~Hz}), 3.14(6 \mathrm{H}, \mathrm{q}, J=7.2 \mathrm{~Hz}), 6.97(1 \mathrm{H}, \mathrm{d}, J=3.6 \mathrm{~Hz})$, $7.69(2 \mathrm{H}, \mathrm{dd}, J=7.8$ and $5.4 \mathrm{~Hz}), 7.75(1 \mathrm{H}, \mathrm{d}, J=3.6 \mathrm{~Hz}), 8.01(2 \mathrm{H}$, dd, $\left.J_{1} \approx J_{2}=7.8 \mathrm{~Hz}\right), 8.36(2 \mathrm{H}, \mathrm{s}), 8.39(2 \mathrm{H}, \mathrm{d}, J=7.7 \mathrm{~Hz}), 8.95(2 \mathrm{H}$, d, $J=5.4 \mathrm{~Hz}$ ). MS (ESI) $m / z(\%)=677(55), 676(26), 675\left([\mathrm{M}]^{+}\right.$, 100), 674 (60), 673 (38), 672 (39), 417 (67). HRMS: $m / z$ (ESI) $[\mathrm{M}]^{+}$ found 675.0069; $\mathrm{C}_{28} \mathrm{H}_{25} \mathrm{~N}_{6} \mathrm{RuS}_{4}$ requires 675.0073.

4.2.3.3. Complex 5c: $E t_{3} N H\left[R u(3 c)(N C S)_{3}\right]$. Black solid (71 \%). ${ }^{1} \mathrm{H}$ $\mathrm{NMR}\left(400 \mathrm{MHz}, \mathrm{CD}_{3} \mathrm{CN}\right) \delta$ (main isomer, approximately $80 \%$ of the total) $1.26(9 \mathrm{H}, \mathrm{t}, J=7.2 \mathrm{~Hz}), 3.94(3 \mathrm{H}, \mathrm{s}), 3.14(6 \mathrm{H}, \mathrm{q}, J=7.2 \mathrm{~Hz}), 3.96$ $(3 \mathrm{H}, \mathrm{s}), 7.11(1 \mathrm{H}, \mathrm{d}, J=8.4 \mathrm{~Hz}), 7.50(1 \mathrm{H}, \mathrm{d}, J=2.1 \mathrm{~Hz}), 7.54(1 \mathrm{H}$, dd, $J=8.4$ and $2.2 \mathrm{~Hz}), 7.67(2 \mathrm{H}, \mathrm{dd}, J=7.5$ and $5.5 \mathrm{~Hz}), 7.97(2 \mathrm{H}$, dd, $J=7.9$ and $7.5 \mathrm{~Hz}), 8.39-8.35(4 \mathrm{H}, \mathrm{m}), 8.95(2 \mathrm{H}, \mathrm{d}, J=5.5 \mathrm{~Hz})$. MS (ESI) $m / z(\%)=646$ (55), $645(25), 644\left([\mathrm{M}]^{+}, 100\right), 643$ (61), 642 (39), 641 (40), 417 (38). HRMS: $m / z$ (ESI) [M] ${ }^{+}$found 644.9777; $\mathrm{C}_{26} \mathrm{H}_{19} \mathrm{~N}_{6} \mathrm{O}_{2} \mathrm{RuS}_{3}$ requires 644.9781.

4.2.3.4. Complex 5d: $E t_{3} N H\left[R u(3 d)(N C S)_{3}\right]$. Black solid (77\%). ${ }^{1} \mathrm{H}$ $\mathrm{NMR}\left(400 \mathrm{MHz}, \mathrm{CD}_{3} \mathrm{CN}\right) \delta$ (main isomer, approximately $80 \%$ of the total) 1.26 (9H, t, $J=7.2 \mathrm{~Hz}), 3.14(6 \mathrm{H}, \mathrm{q}, J=7.2 \mathrm{~Hz}), 6.43-6.39(2 \mathrm{H}, \mathrm{m})$, 7.39-7.35 (2H, m), $7.70(2 \mathrm{H}, \mathrm{dd}, J=7.8$ and $5.3 \mathrm{~Hz}), 7.73(2 \mathrm{H}, \mathrm{d}$,
$J=8.4 \mathrm{~Hz}$ ), $7.99(2 \mathrm{H}, \mathrm{dd}, J=8.1$ and $7.7 \mathrm{~Hz}), 8.14(2 \mathrm{H}, \mathrm{d}, J=8.4$ $\mathrm{Hz}), 8.42(2 \mathrm{H}, \mathrm{d}, J=8.2 \mathrm{~Hz}), 8.50(2 \mathrm{H}, \mathrm{s}), 8.98(2 \mathrm{H}, \mathrm{d}, J=5.3 \mathrm{~Hz}) . \mathrm{MS}$ (ESI) $m / z(\%)=651(53), 649\left([\mathrm{M}]^{+}, 100\right), 648(61), 647(38), 646$ (38), 417 (29). HRMS: $m / z$ (ESI) $[M]^{+}$found 649.9833; $\mathrm{C}_{28} \mathrm{H}_{18} \mathrm{~N}_{7} \mathrm{RuS}_{3}$ requires 649.9839 .

4.2.3.5. Complex 5f: $E t_{3} N H\left[R u(3 f)(N C S)_{3}\right]$. Black solid (76\%). ${ }^{1} \mathrm{H}$ NMR (400 MHz, $\left.\mathrm{CD}_{3} \mathrm{CN}\right) \delta$ (main isomer, approximately $70 \%$ of the total) $1.26(9 \mathrm{H}, \mathrm{t}, J=7.2 \mathrm{~Hz}), 3.00(6 \mathrm{H}, \mathrm{s}), 3.14(6 \mathrm{H}, \mathrm{q}, J=7.2 \mathrm{~Hz})$, $7.32(1 \mathrm{H}, \mathrm{d}, J=7.8 \mathrm{~Hz}), 7.75-7.60(5 \mathrm{H}, \mathrm{m}), 8.00(2 \mathrm{H}, \mathrm{m}), 8.17(1 \mathrm{H}, \mathrm{d}$, $J=8.3 \mathrm{~Hz}$ ), 8.45-8.30 (5H, m), 8.94 (2H, br.d). MS (ESI) $m / z(\%)=$ 680 (56), $678\left([\mathrm{M}]^{+}, 100\right), 677$ (62), 676 (39), 675 (40), 417 (44). HRMS: $m / z$ (ESI) $[\mathrm{M}]^{+}$found $678.0153 ; \mathrm{C}_{30} \mathrm{H}_{22} \mathrm{~N}_{7} \mathrm{RuS}_{3}$ requires 678.0148 .

4.2.3.6. Complex 5g: $\mathrm{Et}_{3} \mathrm{NH}\left[\mathrm{Ru}(3 \mathrm{~g})(\mathrm{NCS})_{3}\right]$. Black Solid $(71 \%) .{ }^{1} \mathrm{H}$ NMR ( $400 \mathrm{MHz}, \mathrm{CD}_{3} \mathrm{CN}$ ) $\delta$ (main isomer, approximately $85 \%$ of the total) $1.26(9 \mathrm{H}, \mathrm{t}, J=7.2 \mathrm{~Hz}), 1.56(3 \mathrm{H}, \mathrm{t}, J=7.2 \mathrm{~Hz}), 3.14(6 \mathrm{H}, \mathrm{q}, J=7.2$ $\mathrm{Hz}), 4.57(2 \mathrm{H}, \mathrm{q}, J=7.1 \mathrm{~Hz}), 7.27(1 \mathrm{H}, \mathrm{t}, J=7.4 \mathrm{~Hz}), 7.43(2 \mathrm{H}, \mathrm{t}$, $J=6.3 \mathrm{~Hz}), 7.65-7.55(4 \mathrm{H}, \mathrm{m}), 7.73(1 \mathrm{H}, \mathrm{d}, J=8.6 \mathrm{~Hz}), 7.99(2 \mathrm{H}, \mathrm{d}$, $J=8.0 \mathrm{~Hz}), 8.06(1 \mathrm{H}, \mathrm{d}, J=8.4 \mathrm{~Hz}), 8.21(1 \mathrm{H}, \mathrm{d}, J=7.6 \mathrm{~Hz}), 8.70$ $(1 \mathrm{H}, \mathrm{s}), 8.25(2 \mathrm{H}, \mathrm{s}), 8.85(2 \mathrm{H}, \mathrm{d}, J=5.1 \mathrm{~Hz})$. MS (ESI) $m / z(\%)=705$ (20), 704 (57), 703 (32), $702\left([\mathrm{M}]^{+}, 100\right), 701$ (63), 700 (40), 699 (39), 696 (16), 442 (10), 440 (16), 419 (9), 418 (23), 417 (95), 404 (15), 403 (62), 397 (11), 389 (31), 375 (16). HRMS: $m / z$ (ESI) [M] ${ }^{+}$ found 702.0142; $\mathrm{C}_{32} \mathrm{H}_{22} \mathrm{~N}_{7} \mathrm{RuS}_{3}$ requires 702.0153.

\subsection{Cyclic voltammetry}

Electrochemical measurements were performed by a BAS 100B/W apparatus. Ligands 3 and complexes $\mathbf{5}$ were dissolved in anhydrous DMF containing $0.1 \mathrm{M}\left[\mathrm{Bu}_{4} \mathrm{~N}\right] \mathrm{PF}_{6}$ and the solutions were kept under a $\mathrm{N}_{2}$ atmosphere. A three electrodes cell was used with Pt as working electrode, Pt wire as counter electrode and $\mathrm{Ag} / \mathrm{Ag}^{+}$as reference electrode (Ag wire in $0.01 \mathrm{M} \mathrm{AgNO}_{3}$ and $0.1 \mathrm{M}\left[\mathrm{Bu}_{4} \mathrm{~N}\right] \mathrm{PF}_{6}$ dissolved in $\mathrm{DMF}$ ). The $\mathrm{Fc} / \mathrm{Fc}^{+}$couple was used to calibrate the reference electrode (in these conditions $\mathrm{E}_{1 / 2}\left(\mathrm{Fc}^{+} / \mathrm{Fc}\right)=+0.470 \mathrm{mV}$ vs SCE, +0.711 vs NHE) [34]. CV experiments were performed at different scan rates 20 , 200 , and $800 \mathrm{mV} / \mathrm{s}$.

\subsection{Nonlinear optical study using the hyper-Rayleigh scattering (HRS) method}

Hyper-Rayleigh scattering (HRS) was used to measure the angleaveraged first hyperpolarizability $\beta$ of the molecules studied [35]. The experimental set-up for hyper-Rayleigh measurements has previously been described in detail [35b]. A Q-switched Nd:YAG laser operating at a $10 \mathrm{~Hz}$ repetition rate with approximately $10 \mathrm{~mJ}$ of energy per pulse and a pulse duration (FWHM) close to 12 ns is used to excite Hyper Rayleigh scattering with an incident wavelength of $1064 \mathrm{~nm}$. The hyper-Rayleigh signal was normalized at each pulse by using a small fraction of the laser pulse to generate a second harmonic signal from a KDP crystal to compensate for fluctuations in the temporal profile of the laser pulses due to longitudinal mode beating. Dioxane and methanol were used as a solvent, and the $\beta$ values were calibrated using a reference solution of $p$-nitroaniline $(p \mathrm{NA})$ also dissolved in dioxane or methanol at a concentration of $1 \times 10^{-2} \mathrm{~mol} \mathrm{dm}^{-3}$ (external reference method) [36]. The hyperpolarizability of $p$ NA dissolved in dioxane or methanol is known from EFISH measurements carried out at the same fundamental wavelength. Following reference [36b] we have chosen to report our values using the so-called $\mathrm{T}$ (Taylor expansion) convention. All solutions were filtered $(0.2 \mu \mathrm{m}$ porosity) to avoid spurious signals from suspended impurities. The small hyper Rayleigh signal that arises from dioxane or methanol was taken into account. We took particular care to avoid reporting artificially high hyperpolarizabilities due to a possible contamination of the hyper Rayleigh signal by molecular 
fluorescence near $532 \mathrm{~nm}$. Measurements were carried out using two different interference filters with different transmission pass bands centred near the second harmonic at $532 \mathrm{~nm}$ allowing us to estimate and correct for any fluorescence emitted near $532 \mathrm{~nm}$.

\section{Acknowledgments}

Thanks are due to Fundação para a Ciência e a Tecnologia and FEDERCOMPETE for financial support through Centro de Química (UID/QUI/ 00686/2013 and UID/QUI/0686/2016), and a PhD grant to S. S. M. Fernandes (SFRH/BD/87786/2012). The NMR spectrometer Bruker Avance III 400 is part of the National NMR Network and was purchased with funds from FCT and FEDER. The pulsed laser system was acquired within the framework of the grant (PTDC/CTM/105597/2008) from the Portuguese Foundation for Science and Technology (FCT) with funding from FEDER-COMPETE.

\section{Appendix A. Supplementary data}

Supplementary data related to this article can be found at http://dx. doi.org/10.1016/j.dyepig.2017.10.046.

\section{References}

[1] (a) Chelucci G, Thummel RP. Chiral 2,2'-bipyridines, 1,10-phenanthrolines, and $2,2^{\prime}: 6$ ',2"-terpyridines: syntheses and applications in asymmetric homogeneous catalysis. Chem Rev 2002;102:3129-70;

(b) Fallahpour R-A. Synthesis of 4'-substituted-2,2':6',2"'-terpyridines. Synthesis 2003;02:155-84;

(c) Heller M, Schubert Ulrich S. Syntheses of functionalized 2,2':6',2"-terpyridines. Eur J Org Chem 2003;6:947-61;

(d) Wild A, Winter A, Schlutter F, Schubert US. Advances in the field of $\pi$-conjugated 2,2':6',2"-terpyridines. Chem Soc Rev 2011;40:1459-511;

(e) Husson J, Knorr M. 2,2':6',2"-Terpyridines functionalized with thienyl substituents: synthesis and applications. J Heterocycl Chem 2012;49:453-78; (f) Saccone D, Magistris C, Barbero N, Quagliotto P, Barolo C, Viscardi G. Terpyridine and quaterpyridine complexes as sensitizers for photovoltaic applications. Materials 2016;9:137.

[2] (a) Constable EC, Davies JE, Phillips D, Raithby PR. Coordination chemistry of 5,5"-disubstituted 2,2':6',2"'-terpyridines. Polyhedron 1998;17:3989-97;

(b) Constable EC. 2,2':6',2"-Terpyridines: from chemical obscurity to common supramolecular motifs. Chem Soc Rev 2007:36:246-53.

[3] (a) O'Regan B, Gratzel M. A low-cost, high-efficiency solar cell based on dye-sensitized colloidal $\mathrm{TiO}_{2}$ films. Nature 1991;353:737-40;

(b) Nazeeruddin MK, Grätzel M. Separation of linkage isomers of trithiocyanato (4,4, 4"-tricarboxy-2, 2',6,2"-terpyridine)ruthenium(II) by pH-titration method and their application in nanocrystalline $\mathrm{TiO}_{2}$-based solar cells. J Photochem Photobiol, A 2001;145:79-86;

(c) Nazeeruddin MK, Péchy P, Renouard T, Zakeeruddin SM, Humphry-Baker R, Comte $\mathrm{P}$, et al. Engineering of efficient panchromatic sensitizers for nanocrystalline $\mathrm{TiO}_{2}$-based solar cells. J Am Chem Soc 2001;123:1613-24;

(d) Mosurkal R, Kim YG, Kumar J, Li L, Walker J, Samuelson LA. Mono- and dinuclear ruthenium complexes for nanocrystalline $\mathrm{TiO}_{2}$ based dye-sensitized photovoltaics. J Macromol Sci, Part A Pure Appl. Chem 2003;40:1317-25; (e) Altobello S, Argazzi R, Caramori S, Contado C, Da Fré S, Rubino P, et al. Sensitization of nanocrystalline $\mathrm{TiO}_{2}$ with black absorbers based on Os and $\mathrm{Ru}$ polypyridine complexes. J Am Chem Soc 2005;127:15342-3;

(f) Aiga F, Tada T. Design of novel efficient sensitizing dye for nanocrystalline $\mathrm{TiO}_{2}$ solar cell; tripyridine-thiolato $\left(4,4^{\prime}, 4^{\prime \prime}\right.$-tricarboxy-2,2':6',2"-terpyridine)ruthenium (II). Sol Energy Mater Sol Cells 2005;85:437-46;

(g) Ghosh S, Chaitanya GK, Bhanuprakash K, Nazeeruddin MK, Grätzel M, Reddy PY. Electronic structures and absorption spectra of linkage isomers of trithiocyanato (4,4',4"-tricarboxy-2,2':6,2"-terpyridine) ruthenium(II) complexes: a DFT study. Inorg Chem 2006;45:7600-11;

(h) Duprez V, Krebs FC. New carboxy-functionalized terpyridines as precursors for zwitterionic ruthenium complexes for polymer-based solar cells. Tetrahedron Lett 2006;47:3785-9;

(i) Duprez V, Biancardo M, Krebs FC. Characterisation and application of new carboxylic acid-functionalised ruthenium complexes as dye-sensitisers for solar cells. Sol Energy Mater Sol Cells 2007;91:230-723;

(j) Lin H-W, Wang Y-S, Huang Z-Y, Lin Y-M, Chen C-W, Yang S-H, et al. Origins of device performance in dicarboxyterpyridine Ru(II) dye-sensitized solar cells. Phys Chem Chem Phys 2012;14:14190-5.

[4] Bolink HJ, Cappelli L, Coronado E, Gaviña P. Observation of electroluminescence at room temperature from a ruthenium(II) bis-terpyridine complex and its use for preparing light-emitting electrochemical cells. Inorg Chem 2005;44:5966-8.

[5] (a) Konstantaki M, Koudoumas E, Couris S, Lainé P, Amouyal E, Leach S. Substantial non-linear optical response of new polyads based on Ru and Os complexes of modified terpyridines. J Phys Chem B 2001;105:10797-804; (b) Roberto D, Tessore F, Ugo R, Bruni S, Manfredi A, Quici S. Terpyridine Zn(II), $\mathrm{Ru}(\mathrm{III})$ and $\mathrm{Ir}(\mathrm{III})$ complexes as new asymmetric chromophores for nonlinear optics: first evidence for a shift from positive to negative value of the quadratic hyperpolarizability of a ligand carrying an electron donor substituent upon coordination to different metal centres. Chem Commun 2002;8:846-7;

(c) Tessore F, Roberto D, Ugo R, Pizzotti M, Quici S, Cavazzini M, et al. Terpyridine $\mathrm{Zn}(\mathrm{II}), \mathrm{Ru}(\mathrm{III})$, and Ir(III) complexes: the relevant role of the nature of the metal ion and of the ancillary ligands on the second-order nonlinear response of terpyridines carrying electron donor or electron acceptor groups. Inorg Chem 2005;44:8967-78; (d) De Angelis F, Fantacci S, Sgamelotti A, Cariati F, Roberto D, Tessore F, et al. A time-dependent density functional theory investigation on the nature of the electronic transitions involved in the nonlinear optical response of $\left[\mathrm{Ru}\left(\mathrm{CF}_{3} \mathrm{CO}_{2}\right)_{3} \mathrm{~T}\right](\mathrm{T}$ $=4^{\prime}-\left(\mathrm{C}_{6} \mathrm{H}_{4}-p-\mathrm{NBu}_{2}\right)-2,2^{\prime}: 6$ ', 2"'-terpyridine $)$. Dalton Trans 2006;6:852-9;

(e) Cariati E, Pizzotti R, Tessore F, Ugo R. Coord Chem Rev 2006;250:1210; (f) Scarpaci A, Monnereau C, Hergue N, Blart E, Legoupy S, Odobel F, et al. Preparation and characterization of second order non-linear optical properties of new "push-pull" platinum complexes. Dalton Trans 2009;23:4538-46; (g) Di Bella S, Dragonetti C, Pizzotti M, Roberto D, Tessore F, Ugo R. Le Bozec H, Guerchais V, editors. Topics in organometallic chemistry 28. Molecular organometallic materials for optics, vol. 28. Springer; 2010. p. 1;

(h) Colombo A, Locatelli D, Roberto D, Tessore F, Ugo R, Cavazzini M, et al. New [(D-terpyridine)-Ru-(D or A-terpyridine)][4-EtPhCO $\left.{ }_{2}\right](2)$ complexes (D = electron donor group; A = electron acceptor group) as active second-order nonlinear optical chromophores. Dalton Trans 2012;41:6707-14.

[6] (a) Barigelletti F, Flamigni L, Calogero G, Hammarstrom L, Sauvage JP, Collin JP. A functionalized ruthenium(II)-bis-terpyridine complex as a rod-like luminescent sensor of zinc(II). Chem Commun 1998;21:2333-4;

(b) Bhaumik C, Das S, Saha D, Dutta S, Baitalik S. Synthesis, characterization, photophysical, and anion-binding studies of luminescent heteroleptic bis-tridentate ruthenium(II) complexes based on 2,6-bis(benzimidazole-2-yl)pyridine and 4'-substituted 2,2':6',2" terpyridine derivatives. Inorg Chem 2010;49:5049-62; (c) Saha D, Das S, Maity D, Dutta S, Baitalik S. Synthesis, structural characterization, and photophysical, electrochemical, intercomponent energy-transfer, and anion-sensing studies of imidazole 4,5-bis(benzimiclazole)-bridged Os(II)-Os(II) and $\mathrm{Ru}(\mathrm{II})-\mathrm{Os}(\mathrm{II})$ bipyridine complexes. Inorg Chem 2011;50:46-61;

(d) Bhaumik C, Saha D, Das S, Baitalik S. Synthesis, structural characterization, photophysical, electrochemical, and anion-sensing studies of luminescent homoand heteroleptic ruthenium(II) and osmium(II) complexes based on terpyridylimidazole ligand. Inorg Chem 2011;50:12586-600;

(e) Bhaumik C, Maity D, Das S, Baitalik S. Anion sensing studies of luminescent bistridentate ruthenium(II) and osmium(II) complexes based on terpyridyl-imidazole ligand through different channels. Polyhedron 2013;52:890-9;

(f) Maity D, Bhaumik C, Mondal D, Baitalik S. Ru(II) and Os(II) complexes based on terpyridyl-imidazole ligand rigidly linked to pyrene: synthesis, structure, photophysics, electrochemistry, and anion-sensing studies. Inorg Chem 2013;52:13941-55;

(g) Maity D, Das S, Mardanya S, Baitalik S. Synthesis, structural characterization, and photophysical, spectroelectrochemical, and anion-sensing studies of heteroleptic ruthenium(II) complexes derived from 4'-polyaromatic-substituted terpyridine derivatives and 2,6-bis(benzimidazol-2-yl)pyridine. Inorg Chem 2013;52:6820-38;

(h) Naidji B, Husson J, Taouil AE, Brunol E, Sanchez JB, Berger F, et al. Terpyridine-based metallopolymer thin films as active layer in ammonia sensor device. Synth Met 2016;221:214-9;

(i) Chao D, Ni S, Mu W. One-pot synthesis of a terpyridine derivate with selective fluorescence response to $\mathrm{Zn}^{2+}$ in aqueous solution and its application in bioimaging. Chem Lett 2016;45:27-9.

[7] (a) Arena G, Scolaro LM, Pasternack RF, Romeo R. Synthesis, characterization, and interaction with DNA of the novel metallointercalator cationic complex $(2,2$ ':6',2"' terpyridine)methylplatinum(II). Inorg Chem 1995;34:2994-3002;

(b) Gao H, Reibenspies JH, Martell AE. Synthesis and DNA binding properties of a cationic 2,2':6',2"-terpyridine, cobalt(II) complex containing an oligopeptide. J Inorg Biochem 2003;94:272-8;

(c) Shi PF, Jiang Q, Zhao YM, Zhang YM, Lin J, Lin LP, et al. DNA binding properties of novel cytotoxic gold(III) complexes of terpyridine ligands: the impact of steric and electrostatic effects. J Biol Inorg Chem 2006;11:745-52;

(d) Ma Z, Cao YQ, Li QS, da Silva M, da Silva J, Pombeiro AJL. Synthesis, characterization, solid-state photo-luminescence and anti-tumor activity of zinc(II) 4'phenyl-terpyridine compounds. J Inorg Biochem 2010;104:704-11;

(e) Banerjee S, Kitchen JA, Bright SA, O'Brien JE, Williams DC, Kelly JM, et al. Synthesis, spectroscopic and biological studies of a fluorescent Pt(II) (terpy) based 1,8-naphthalimide conjugate as a DNA targeting agent. Chem Commun 2013;49:8522-4;

(f) Chatterjee S, Norton AE, Edwards MK, Peterson JM, Taylor SD, Bryan SA, et al. Highly selective colorimetric and luminescence response of a square-planar platinum(II) terpyridyl complex to aqueous $\mathrm{TcO}_{4}$. Inorg Chem 2015;54:9914-23; (g) Trigo-Lopez M, Munoz A, Ibeas S, Serna F, Garcia FC, Garcia JM. Colorimetric detection and determination of $\mathrm{Fe}(\mathrm{III}), \mathrm{Co}(\mathrm{II}), \mathrm{Cu}(\mathrm{II})$ and $\mathrm{Sn}(\mathrm{II})$ in aqueous media by acrylic polymers with pendant terpyridine motifs. Sens Actuator B-Chem 2016;226:118-26.

[8] (a) Kwong H-L, Yeung H-L, Yeung C-T, Lee W-S, Lee C-S, Wong W-L. Chiral pyridine-containing ligands in asymmetric catalysis. Coord Chem Rev 2007;251:2188-222;

(b) Winter A, Newkome GR, Schubert US. Catalytic applications of terpyridines and their transition metal complexes. ChemCatChem 2011;3:1384-406. 
[9] (a) Navarro M, De Giovani WF, Romero JR. Electrocatalytic oxidation of alcohols and diols using polypyridyl complexes of ruthenium. Effect of the redox potential on selectivity. J Mol Catal A Chem 1998;135:249-56;

(b) Lebeau EL, Meyer TJ. Oxidation of benzyl alcohol by a dioxo complex of ruthenium(VI). Inorg Chem 1999;38:2174-81.

[10] Shen J, Brodbelt JS. Complexation of polyethers and pyridyl ligands with monopositive transition metal ions in the gas phase. Int J Mass Spectrom 1998;176:39-61.

[11] Alvila L, Pakkanen TA, Krause O. Hydroformylation of olefins catalysed by supported $\mathrm{Ru}_{3}(\mathrm{CO})_{12}$ with 2,2'-bipyridine or with other heterocyclic nitrogen base. J Mol Catal 1993;84:145-56.

[12] Limburg J, Crabtree RH, Brudvig GW. Kinetic analysis of the $\mathrm{O}_{2}$-forming reaction between $\left[\mathrm{Mn}(\mathrm{III})(\mathrm{dpa})_{2}\right]-(\mathrm{dpa}=$ dipicolinate $)$ and potassium peroxomonosulfate. Inorg Chim Acta 2000;297:301-6.

[13] (a) Hanan GS, Arana CR, Lehn J-M, Baum G, Fenske D. Coordination arrays: synthesis and characterisation of rack-type dinuclear complexes. Chem Eur J 1996;2:1292-302;

(b) Constable E C. Metallodendrimers: metal ions as supramolecular glue. Chem Commun 1997;12:1073-80;

(c) Constable E C, Phillips D. Five-component assembly of molecular loops. Chem Commun 1997;9:827-8;

(d) Baum GC, Constable E, Fenske DE, Housecroft C, Kulke T. Solvent control in the formation of mononuclear and dinuclear double-helical silver(I)-2,2':6',2"'-terpyridine complexes. Chem Commun 1998;23:2659-60;

(e) Belfrekh N, Dietrich-Buchecker C, Sauvage J-P. Unexpected synthesis of an 8shaped macrocycle instead of an interlocking-ring system. Inorg Chem 2000;39:5169-72;

(f) Albrecht M. "Let's twist again" - double-atranded, triple-stranded, and circular helicates. Chem Rev 2001;101:3457-98;

(g) Schubert US, Eschbaumer C, Hien O, Andres PR. 4'-Functionalized 2,2':6',2"terpyridines as building blocks for supramolecular chemistry and nanoscience. Tetrahedron Lett 2001;42:4705-7;

(h) Hofmeier H, Andres PR, Hoogenboom R, Herdtweck E, Schubert US. Terpyridine-ruthenium complexes as building blocks for new metallo-supramolecular architectures. Aust J Chem 2004;57:419-26.

[14] Schubert US, Hofmeier H, Newkome GR. Modern terpyridine chemistry. Weinheim: Wiley-VCH Verlag GmbH \& Co. KGaA; 2006.

[15] Morgan GT, Burstall FH. 3. Dehydrogenation of pyridine by anhydrous ferric chloride. J Chem Soc 1932:20-30.

[16] (a) Kröhnke F. The specific synthesis of pyridines and oligopyridines. Synthesis 1976;01:1-24;

(b) Potts KT, Usifer DA, Guadalupe A, Abruna HD. 4-Vinyl-, 6-vinyl-, and 4'-vinyl2,2 ':6',2"-terpyridinyl ligands: their synthesis and the electrochemistry of their transition-metal coordination complexes. J Am Chem Soc 1987;109:3961-7; (c) Tu S, Jia R, Jiang B, Zhang J, Zhang Y, Yao C, et al. Kröhnke reaction in aqueous media: one-pot clean synthesis of 4'-aryl-2,2':6',2"-terpyridines. Tetrahedron 2007;63:381-8.

[17] Miyaura N, Suzuki A. Palladium-catalyzed cross-coupling reactions of organoboron compounds. Chem Rev 1995;95:2457-83.

[18] Stille JK. The palladium-catalyzed cross-coupling reactions of organotin reagents with organic electrophiles. Angew Chem Int Ed Engl 1986;25:508-24.

[19] (a) Cárdenas DJ, Sauvage J-P. Improved synthesis of 2,6-oligopyridines by Stille cross-coupling reaction. Synlett 1996;09:916-8;

(b) Fallahpour R-A. An efficient and easy route to trimethyl derivatives of 2,2':6',2"-terpyridine. Synthesis 2000;12:1665-7;

(c) Ulrich G, Bedel S, Picard C, Tisnès P. Synthesis of bisfunctionalized-oligopyridines bearing an ester group. Tetrahedron Lett 2001;42:6113-5.

[20] (a) Suzuki A. Cross-coupling reactions of organoboranes: an easy way to construct C-C Bonds. Angew Chem Int Ed 2011;50:6722-37;

(b) Cordovilla C, Bartolomé C, Martínez-Ilarduya JM, Espinet P. The Stille reaction, 38 years later. ACS Catal 2015;5:3040-53.

[21] Tohda Y, Eiraku M, Nakagawa T, Usami Y, Ariga M, Kawashima T, et al, Nucleophilic reaction upon electron-deficient pyridone derivatives. One-pot synthesis of 3-nitropyridines by ring transformation of 1-methyl-3,5-dinitro-2-pyridone with ketones or aldehydes in the presence of ammonia. Bull Chem Soc Jpn 1990;63:2820-7.

[22] Pabst GR, Sauer J. The new and simple 'LEGO' system: its application to the synthesis of 4-stannyl-, 4-bromo- and branched oligopyridines. Tetrahedron 1999;55:5067-88.

[23] Newkome GR, Fishel DL. Pyrolysis of ketone $N, N, N$-trimethylhydrazonium fluoroborates. Evidence for the genesis of pyridines. J Org Chem 1972;37:1329-36.

[24] (a) Fonseca AM, Raposo MMM, Sousa AMRC, Kirsch G, Beley M. Synthesis and electrochemical and spectroscopic properties of molybdenum complexes bearing 5Alkoxythiophene or -bithiophene groups. Eur J Inorg Chem 2005;21:4361-5; (b) Batista RMF, Costa SPG, Belsley M, Lodeiro C, Raposo MMM. Synthesis and characterization of novel (oligo)thienyl-imidazo-phenanthrolines as versatile $\pi$ conjugated systems for several optical applications. Tetrahedron 2008;64:9230-8; (c) Batista RMF, Costa SPG, Belsley M, Raposo MMM. Synthesis and optical properties of novel, thermally stable phenanthrolines bearing an arylthienyl-imidazo conjugation pathway. Dyes Pigments 2009;80:329-36;

(d) Fonseca AM, Belsley M, Gomes EM, Castro MCR, Raposo MMM. Molybdenum complexes bearing (bi)thienyl- or arylthienyl-substituted $\pi$-conjugated spacers: synthesis, electrochemical, spectroscopic and nonlinear optical properties. Eur J
Inorg Chem 2010;19:2998-3004;

(e) Mohammed N, Wiles AA, Belsley M, Fernandes SSM, Cariello M, Rotello VM, et al. Synthesis and characterisation of push-pull flavin dyes with efficient second harmonic generation (SHG) properties. RSC Adv 2017;7:24462-9.

[25] Marín-Hernández C, Santos-Figueroa LE, El Sayed S, Pardo T, Raposo MMM, Batista RMF, et al. Synthesis and evaluation of the chromo-fluorogenic recognition ability of imidazoquinoline derivatives toward ions. Dyes Pigments 2015;122:50-8.

[26] Pedras B, Batista RMF, Tormo L, Costa SPG, Raposo MMM, Orellana G, et al. Synthesis, characterization, photophysical studies and interaction with DNA of a new family of $\mathrm{Ru}(\mathrm{II})$ furyl- and thienyl-imidazo-phenanthroline polypyridyl complexes. Inorg Chim Acta 2012;381:95-103.

[27] (a) Costa F, Silva CJR, Raposo MMM, Fonseca AM, Neves IC, Carvalho AP, et al. Synthesis and immobilization of molybdenum complexes in a pillared layered clay. Microporous Mesoporous Mater 2004;72:111-8;

(b) Figueiredo H, Silva B, Raposo MMM, Fonseca AM, Neves IC, Quintelas C, et al. Immobilization of $\mathrm{Fe}(\mathrm{III})$ complexes of pyridazine derivatives prepared from biosorbents supported on zeolites. Microporous Mesoporous Mater 2008;109:163-71; (c) Figueiredo H, Silva B, Quintelas C, Raposo MMM, Parpot P, Fonseca AM, et al. Immobilization of chromium complexes in zeolite $\mathrm{Y}$ obtained from biosorbents: synthesis, characterization and catalytic behaviour. Appl Catal B Environ 2010;94:1-7;

(d) Kuźniarska-Biernacka I, Raposo MMM, Batista R, Parpot P, Biernacki K, Magalhães AL, et al. Highly efficient heterogeneous catalysts for phenol oxidation: binuclear pyrrolyl-azine metal complexes encapsulated in NaY zeolite. Microporous Mesoporous Mater 2016;227:272-80.

[28] (a) Constable EC, Dunphy EL, Housecroft CE, Neuburger M, Schaffner S, Schaper F, et al. Expanded ligands: $b i s(2,2 ': 6$ ',2"-terpyridine carboxylic acid)ruthenium(II) complexes as metallosupramolecular analogues of dicarboxylic acids. Dalton Trans 2007;38:4323-32;

(b) Mahendiran D, Kumar RS, Viswanathan V, Velmurugan D, Rahiman AK. Targeting of DNA molecules, BSA/c-Met tyrosine kinase receptors and anti-proliferative activity of bis(terpyridine)copper(II) complexes. Dalton Trans 2016;45:7794-814.

[29] Mahendiran D, Gurumoorthy P, Gunasekaran K, Senthil Kumar R, Rahiman AK. Structural modeling, in vitro antiproliferative activity, and the effect of substituents on the DNA fastening and scission actions of heteroleptic copper(II) complexes with terpyridines and naproxen. New J Chem 2015;39:7895-911.

[30] Wang CX, Li L, Yu WT, Yang JX, Wu JY. 4'[4-(Imidazole-1-yl)phenyl]-2,2':6',2"'terpyridine (IPTP). Acta Crystallogr Sect e 2006;62:0246-8.

[31] (a) Vougioukalakis GC, Stergiopoulos T, Kantonis G, Kontos AG, Papadopoulos K, Stublla A, et al. Terpyridine- and 2,6-dipyrazinylpyridine-coordinated ruthenium (II) complexes: synthesis, characterization and application in $\mathrm{TiO}_{2}$-based dye-sensitized solar cells. J Photochem Photobiol A 2010;214:22-32;

(b) Brewster TP, Ding W, Schley ND, Hazari N, Batista VS, Crabtree RH. Thiocyanate linkage isomerism in a ruthenium polypyridyl complex. Inorg Chem 2011;50:11938-46.

[32] D'Aléo A, Cecchetto E, Cola LD, Williams RM. Metal ion enhanced charge transfer in a terpyridine-bis-pyrene system. Sensors 2009;9:3604-26.

[33] Yang S-H, Wu K-L, Chi Y, Cheng Y-M, Chou P-T. Tris(thiocyanate) ruthenium(II) sensitizers with functionalized dicarboxyterpyridine for dye-sensitized solar cells. Angew Chem Int Ed 2011;50:8270-4.

[34] Aranzaes JR, Daniel M-C, Astruc D. Metallocenes as references for the determination of redox potentials by cyclic voltammetry - permethylated iron and cobalt sandwich complexes, inhibition by polyamine dendrimers, and the role of hydroxycontaining ferrocenes. Can J Chem 2006;84:288-99.

[35] (a) Clays K, Persoons A. Hyper-Rayleigh scattering in solution. Phys Rev Lett 1991;66:2980-3;

(b) Clays K, Persoons A. Hyper-Rayleigh scattering in solution. Rev Sci Instrum 1992;63:3285-9.

[36] (a) Teng CC, Garito AF. Dispersion of the nonlinear second-order optical susceptibility of organic systems. Phys Rev B 1983;28:6766-73;

(b) Stähelin M, Burland DM, Rice JE. Solvent dependence of the second order hyperpolarizability in p-nitroaniline. Chem Phys Lett 1992;191:245-50; (c) Kaatz P, Shelton DP. Polarized hyper-Rayleigh light scattering measurements of nonlinear optical chromophores. J. Chem Phys 1996;105:3918-29;

(d) Reis H. Problems in the comparison of theoretical and experimental hyperpolarizabilities revisited. J Chem Phys 2006;125:014506;

(e) Huyskens FL, Huyskens PL, Persoons AP. Solvent dependence of the first hyperpolarizability of $p$-nitroanilines: differences between nonspecific dipole-dipole interactions and solute-solvent H-bonds. J Chem Phys 1998;108:8161-71.

[37] (a) Oudar JL. Optical nonlinearities of conjugated molecules: stilbene derivatives and highly polar aromatic compounds. J Chem Phys 1977;67(2):446-57;

(b) Oudar JL, Chemla DS. Hyperpolarizabilities of the nitroanilines and their relations to the excited state dipole moment. J Chem Phys 1977;66(6):2664-8; (c) Oudar JL, Zyss J. Structural dependence of nonlinear-optical properties of methyl-(2,4-dinitrophenyl)-aminopropanoate crystals. Phys Rev A 1982;26(4):2016-27.

[38] Montalti M, Credi A, Prodi L, Gandolfi MT. Handbook of photochemistry. third ed. Boca Raton: CRC Press; 2006.

[39] Sullivan BP, Calvert JM, Meyer TJ. Cis-trans isomerism in (trpy) $\left(\mathrm{PPh}_{3}\right) \mathrm{RuC1}_{2}$. Comparisons between the chemical and physical properties of a cis-trans isomeric pair. Inorg Chem 1980;19:1404-7. 